\title{
Prenatal and postnatal ethanol experiences modulate consumption of the drug in rat pups, without impairment in the granular cell layer of the main olfactory bulb
}

\author{
Mariana Pueta ${ }^{a, b, c,},{ }^{*}$, Roberto A. Rovasio $^{\mathrm{b}}$, Paula Abate ${ }^{\mathrm{a}, \mathrm{c}}$, Norman E. Spear ${ }^{\mathrm{d}}$, and Juan C. \\ Molina ${ }^{a, c, d}$ \\ a Instituto de Investigación Médica M. y M. Ferreyra (INIMEC-CONICET), Córdoba, C.P 5016, \\ Argentina \\ b CEBICEM, Fac. de Cs. Exactas, Físicas y Naturales, Universidad Nacional de Córdoba, \\ Argentina \\ c Facultad de Psicología, Universidad Nacional de Córdoba, Córdoba, Argentina \\ d Center for Developmental Psychobiology, Binghamton University, Binghamton, NY 13902-6000, \\ USA
}

\begin{abstract}
The effect of moderate exposure to ethanol during late gestation was studied in terms of its interaction with moderate exposure during nursing from an intoxicated dam. A further issue was whether behavioral effects of ethanol, especially the enhanced ethanol intake known to occur after moderate ethanol prenatally or during nursing, depend upon teratological effects that may include death of neurons in the main olfactory bulb (MOB). During gestational days 17-20 rats were given 0,1 or $2 \mathrm{~g} / \mathrm{kg}$ ethanol doses intragastrically (i.g.). After parturition these dams were given a dose of $2.5 \mathrm{~g} / \mathrm{kg}$ ethanol i.g. each day and allowed to perform regular nursing activities. During postnatal days (PDs) 15 and 16, ethanol intake of pups was assessed along with aspects of their general activity. In a second experiment pups given the same prenatal treatment as above were tested for blood ethanol concentration (BEC) in response to an ethanol challenge on PD6. A third experiment (Exp. 2b) assessed stereologically the number of cells in the granular cell layer of the MOB on PD7, as a function of analogous pre- and postnatal ethanol exposures. Results revealed that ethanol intake during the third postnatal week was increased by prenatal as well as postnatal ethanol exposure, with a few interesting qualifications. For instance, pups given $1 \mathrm{~g} / \mathrm{kg}$ prenatally did not have increased ethanol intake unless they also had experienced ethanol during nursing. There were no effects of ethanol on either BECs or conventional teratology (cell number). This increases the viability of an explanation of the effects of prenatal and early postnatal ethanol on later ethanol intake in terms of learning and memory.
\end{abstract}

\section{Keywords}

Ethanol; Fetus; Preweanling; Intake; Olfactory bulb; Rats

\footnotetext{
${ }^{*}, 1$ Corresponding author, current address: Laboratorio de Fotobiología INIBIOMA (UNCo-CONICET), Quintral 1250 (8400), S. C. de Bariloche, Río Negro, Patagonia Argentina. Tel/Fax: +54 02944 433040. mpueta@ gmail.com.

Publisher's Disclaimer: This is a PDF file of an unedited manuscript that has been accepted for publication. As a service to our customers we are providing this early version of the manuscript. The manuscript will undergo copyediting, typesetting, and review of the resulting proof before it is published in its final citable form. Please note that during the production process errors may be discovered which could affect the content, and all legal disclaimers that apply to the journal pertain.
} 


\section{Introduction}

Olfaction is functional during fetal life and diverse psychobiological responses that newborns and infants display are dependent on fetal and early postnatal experiences [1,2]. Olfactory cues from the mother and siblings, and odors associated with the rearing context, are particularly important for establishing the behavioral repertoire of developing organisms [3-6]. Several studies in humans and other mammalian species have demonstrated that prenatal experiences with chemosensory information from the maternal diet influence postnatal processing of similar chemosensory cues and could regulate the hedonic value of those early experiences [7-12].

Intraoral infusion of chemosensory cues to near-term rat fetuses elicits behavioral responses in terms of motor or autonomic changes, indicating that olfactory processes are occurring [13-15]. In rodent fetuses the main olfactory system (MOS) appears to be the dominant system responsible of processing chemical stimuli in utero $[1,16,17)$. In human fetuses, the MOS is functional during the last gestational trimester in terms of odor detection and discrimination, and also appears to mediate olfactory learning and memory processes $[10,18]$.

Ethanol is processed for the fetus as a chemosensory cue. Despite immaturity of MOS, fetuses can sense ethanol cues and retain information about that prenatal experience. In addition, associations between ethanol chemosensory cues and other stimuli with biological relevance occur during late gestation [19-22]. Several studies have demonstrated that ethanol distribution in amniotic fluid promotes fetal processing of ethanol's chemosensory features during late gestation and influences postnatal patterns of ethanol recognition, acceptance and consumption [23-27].

Studies in preweanling rats have confirmed that experience with low to moderate ethanol doses $(1.0$ or $2.0 \mathrm{~g} / \mathrm{kg}$ ) during late gestation promotes an increase in the drug's palatability [24,28] and increases consumption of moderately concentrated ethanol solutions $(5.0$ or $6.0 \%)$ [24,25,28-30]. Furthermore, several studies have demonstrated that this increase in palatability and/or ingestive responsiveness to ethanol cues generalize to a configuration of sucrose and quinine, a solution that seems to resemble ethanol's psychophysical characteristics $[24,25,28]$.

Despite the well-known teratogenic effects of ethanol [31], ethanol doses $(1.0$ or $2.0 \mathrm{~g} / \mathrm{kg})$ employed in previous cited studies with rats were selected knowing that obvious macroscopically teratological effects, commonly observed when fetuses are prenatally exposed to higher ethanol levels of the drug, are absent at these concentrations $[19,23,25,31]$.

A study of human neonates showed that maternal consumption during pregnancy modulated neonatal responsiveness to the smell of ethanol [32]. Babies born to mothers classified as frequent drinkers consistently responded to ethanol odor when compared with babies without prenatal ethanol experience, an effect that apparently is independent of gross teratological effects of the drug [32].

As a whole, the evidence indicates that prenatal ethanol experience with low or moderate doses of ethanol biases responses to the drug during infancy. It has been proposed that infantile responses to ethanol could be determined by prenatal exposure to ethanol's sensory attributes during late gestation, by the processing of postabsortive reinforcing effects of ethanol and/or by associative learning mediated by pairing of ethanol's sensory and postabsortive effects [19,33-36]. Animal models have confirmed that exposure to ethanol during late gestation can generate fetal learning of a conditioned preference for the drug's 
orosensory characteristics [29]. The opioid system has seemed to provide a primary neurobiological basis for that associative learning $(28,30,37]$.

Likewise, rat pups $[38,40,41]$ and human infants $[38,42]$ seem capable of processing low ethanol concentrations present in milk during the nursing period. Studies have shown that after interacting with an ethanol-intoxicated mother, preweanling rats change their response to ethanol in terms of reactivity to its chemosensory properties as well as in consumption patterns of ethanol $[43,44,45]$. Ethanol can disrupt maternal care and pups have seemed to associate such maternal changes with the ethanol odor present in the rearing context, leading to an aversion to this odor $[43,46]$.

A few studies have analyzed the interaction between ethanol experiences during late gestation and those in the postnatal period $[26,27,47]$. A previous study demonstrated that consumption of minimal ethanol concentrations during infancy could be influenced by maternal intoxication during pre- and early postnatal periods [27]. Disruption in maternal care, a consequence of ethanol administration in the nursing context, was found to be decreased if the dam previously had received ethanol during the late gestation period $[27,48,49]$. This implies that ethanol experience during gestation and lactation could facilitate social and/or nutritional transmission of the drug's cues and influence the profile of response to ethanol by the offspring.

The first goal of the present study was to assess the effect of early ethanol experience comprising ingestion and perception of the drug in the amniotic fluid and during nursing on consumption of ethanol during the third postnatal week. In the first experiment, pregnant rats were administered one of two ethanol doses $(1.0$ or $2.0 \mathrm{~g} / \mathrm{kg}$ ) or water during gestational days (GDs) 17-20. After birth, pups suckled from dams given ethanol or water during nursing. On postnatal days 15 and 16, these pups were evaluated in terms of ethanol consumption patterns of varying ethanol concentrations.

The generation of early memories related to ethanol exposure during pre- and/or postnatal periods involves a chemosensory component of the ethanol. Given that prenatal olfaction involves MOS, the main olfactory bulb (MOB) is the first location for processing olfactory information in the brain [50]. The olfactory bulb is considered not only the first central relay of the olfactory system, at least in mammals, but also the major site of integration for the olfactory information and a critical structure involved in several cases of learning and memory [51-54]. In addition, MOB is one of the few brain areas of the newborn that continuously integrates local circuit neurons [periglomerular and granule cells (GCs)] within the glomerular and granular cell layer (GCL) [55-58]. During late gestation neuroblasts migrate toward the MOB of the developing organism, with the highest rate occurring during the neonatal period [55,59-62]. The neonatal GCs (GABAergic interneuron) constitute a uniform population that could undergo substantial modifications (e.g., cell number) attributable to early olfactory experiences and that has higher survival rate than adult newborn neurons [52]. Several studies have found that regulation (neurogenesis or neuromodulation) of the GABAergic interneuron plays a significant role in olfactory function including odor detection and discrimination, and is critical for learning and retrieval of specific olfactory memories [54,63-68].

All the preceding evidence pertinent to olfactory bulb function and early olfactory learning involving ethanol supports the second aim of the present study. This second goal was to estimate cell number in GCL of the MOB in rat neonates (PD 7) as a function of maternal ethanol treatment during GDs 17-20. Additionally we included a second factor that was a single administration of ethanol $(1.5 \mathrm{~g} / \mathrm{kg})$ at PD 6 , on the basis of that this postnatal stage is considered as the "brain growth spurt" period described as particularly vulnerable to ethanol 
neurotoxicity[69-71] . This experiment included a preliminary study conducted to evaluate neonatal ethanol metabolism profiles, as a function of prenatal treatment with ethanol.

This second goal was considered because, at present, so few studies have analyzed brain teratogenic effects of low or moderate ethanol doses. Among these is a recent study indicating that low ethanol doses $(<1.0 \mathrm{~g} / \mathrm{kg})$ could interfere with the migration of granular cells in neonate mouse cerebellum [72]. In fact, cell migration is considered one of the developmental processes most vulnerable to ethanol effects [73,74]. Although it is a process that, together with cell proliferation, occurs mainly at the beginning of gestation, some cell populations proliferate and migrate later in development as interneurons of the MOB $[59,75]$. In the MOB, several studies have analyzed structural changes in cell layers utilizing much higher ethanol doses $(5.0-6.0 \mathrm{~g} / \mathrm{kg})$, while employing chronic prenatal administration and/or a postnatal model that includes "artificial rearing"[76,77].

The teratological perspective has prevailed in studies of effects of prenatal ethanol exposure. Despite the limited teratological evidence observable when low or moderate ethanol doses are employed, this perspective could overshadow the possibility that immature organisms are capable of acquiring, retaining and expressing sensory learning as a function of these early experiences with the drug.

In summary, the present study was carried out under experimental conditions that modulate acquisition and/or expression of chemosensory learning during ontogenetic stages characterized by the emergence of functional sensory and learning capabilities. We studied the generation of ethanol-related memories mediated by ethanol's exposure during late gestation and the early postnatal period, and its possible coexistence with altered structural parameters in the GCL of the MOB.

\section{Experiment 1}

Experiment 1 examined preweanling consumption patterns of various ethanol concentrations as a function of repeated exposure to ethanol during late gestation and the first two postnatal weeks. Pregnant dams received either water or 1.0 or $2.0 \mathrm{~g} / \mathrm{kg}$ ethanol doses during GDs 1720. After birth, pups suckled from dams subjected to a $2.5 \mathrm{~g} / \mathrm{kg}$ ethanol dose or water during nursing. On PDs 15 and 16, pups were evaluated in terms of consumption of ethanol solutions $(5.0 \% \mathrm{v} / \mathrm{v}$ or $10.0 \% \mathrm{v} / \mathrm{v})$ or water. In addition, we examined motor activity patterns of pups during the intake test. This additional dependent variable was included because experimental and clinical studies have demonstrated that organisms with a history of ethanol exposure during early ontogeny exhibit a wide range of cognitive and behavioral deficits, among them, hyperactivity, delayed motor development and attentional problems $[78,79]$.

\subsection{Materials and Methods}

2.1.1. Subjects-Wistar-derived pregnant rats were used $(n=52)$. These animals were born and reared at the vivarium of the Instituto Ferreyra (INIMEC-CONICET), under temperature- $\left(22-24^{\circ} \mathrm{C}\right)$ and light- (on from 08:00-20:00 h) controlled conditions. Unless specified, maternal enriched lab chow (Cargill, Buenos Aires, Argentina) and water (delivered through automatic dispenser valves) were available ad libitum. Vaginal smears of adult female rats were microscopically analyzed on a daily basis. On the day of proestrus, females (pre-pregnancy weight 200-300 g) were housed during the dark cycle with males (three females per male). Vaginal smears were checked the following morning (10:00-12:00 h), and the presence of sperm was considered an index of fecundity. The day of sperm detection was considered as GD 0. Births were checked daily (10:00-12:00 h) and the day of parturition was considered as PD 0. During PD 1, each litter was randomly culled to eight 
pups (four males and four females, whenever possible). Pregnant females or litters were individually placed in standard maternity cages filled with wood shavings. At all times, animals utilized in this study were maintained and treated under guidelines for animal care established by the National Institutes of Health [80].

\subsubsection{Maternal drug treatment}

Prenatal Treatment: From GDs 17 to 20, pregnant females were weighed and i.g. administered $0.015 \mathrm{ml} / \mathrm{g}$ of a $8.4 \% \mathrm{v} / \mathrm{v}$ ethanol solution (vehicle: room temperature tap water; ethanol dose: $1.0 \mathrm{~g} / \mathrm{kg}$; Prenatal Ethanol 1 Group (EtOH 1); $n=19$ ), a $16.8 \% \mathrm{v} / \mathrm{v}$ ethanol solution (vehicle: room temperature tap water; ethanol dose: $2.0 \mathrm{~g} / \mathrm{kg}$; Prenatal Ethanol 2 Group (EtOH 2); $n=17$ ) or a similar volume of water (Prenatal Water Group; $n=$ 16). The ethanol dose and the days of administration were selected on the basis of prior studies demonstrating fetal chemosensory processing of the drug under similar experimental circumstances $[21,23,25,27]$. I.g. intubations were performed employing a polyethylene cannula (PE 50; Clay Adams, Parsippany, New Jersey, U.S.A.) attached to a disposable 5-ml syringe. The free end of the cannula was carefully eased into the stomach of the dam. The whole administration procedure took less than $20 \mathrm{~s}$ per animal, and was accompanied by little indication of stress.

Postnatal Treatment: During PDs 3, 5, 7, 9, 11, and 13, half of the mothers representative of each prenatal treatment were administered (i.g.) with $2.5 \mathrm{~g} / \mathrm{kg}$ of ethanol (Postnatal Ethanol Group (EtOH); $n=25)$. The ethanol dose was achieved by administering $0.015 \mathrm{ml}$ of a $21 \% \mathrm{v} / \mathrm{v}$ ethanol solution per gram of maternal body weight. The remaining dams were administered an equivalent volume of tap water (Postnatal Water Group (Water); $n=27$ ). I.g. administrations were performed employing procedures similar to those utilized during gestation.

\subsubsection{Preweanling intake test and behavioral evaluation procedures-During} PDs 15 and 16, 310 pups representative of the different litters were intraorally cannulated with polyethylene tubing (length, $5 \mathrm{~cm}$; PE10, Clay Adams, Parsippany, New Jersey, U.S.A.). The intraoral cannulation procedure has been extensively described in previous studies $[23,39,43,81,82]$. Briefly, a flanged end of the cannula (external diameter, $1.2 \mathrm{~mm}$ ) was shaped by exposure to a heat source. A short dental needle (30GA Monoject, Sherwood Medical, Munchen, Germany) was attached to the nonflanged end and positioned in the middle portion of the internal mucosa of the pup's left cheek. The needle was inserted through the cheek, and the cannula was pulled through the tissue until the flanged end rested on the mouth's mucosa. This cannulation procedure did not last more than $20 \mathrm{~s}$ per subject. As demonstrated by prior studies, pups rapidly recover from this minor surgical intervention $[83,84]$. Pups at this developmental stage are able to control ingestion of fluids delivered via these polyethylene devices $[25,34,39]$. The technique is also sensitive in terms of evaluating learning experiences that comprise the association between a given taste and an unconditioned stimulus [27,85-87].

Following the cannulation procedure, pups were maintained with their corresponding littermates in clean plastic cages for 2 consecutive hours. The use of heating pads placed beneath these chambers allowed maintenance of ambient temperature at $32^{\circ} \mathrm{C}$. Immediately before commencement of the intake test, all pups were stimulated in the anogenital area with a cotton swab to induce miction and defecation. Preweanlings were then weighed $( \pm 0.01 \mathrm{~g})$, and this value was taken as the preinfusion body weight. Each pup was placed in an individual Plexiglas chamber $(15 \times 7 \times 15 \mathrm{~cm})$ lined with a cotton floor, and the cannula was attached to a 10-way peristaltic infusion pump (Manostat Cassette Pump, Standard Model, Barnant Co., Barrington, Illinois, U.S.A.). Pups representative of each litter were 
quasirandomly assigned to receive water, $5.0 \%$ ethanol (v/v) or $10.0 \%$ ethanol (v/v). The liquid was delivered into the rat mouth during $10 \mathrm{~min}$ using a pulsate mode of administration ( $3 \mathrm{~s}$ on, $10 \mathrm{~s}$ off). The rate of infusion was adjusted for each individual rat in order to infuse a total amount of fluid that was equivalent to $1.83 \%$ of the pup's preinfusion body weight ( \pm $0.01 \mathrm{~g})$. At the end of each intake session, pups were removed and weighed again (postinfusion body weight).

Water intake scores were expressed in terms of percentage of total infusion actually consumed (\% ML): [100 $\times(($ postinfusion body weight - preinfusion body weight $) / \mathrm{ml}$ infused)]. Ethanol intake scores were calculated in terms of percentage consumed and also in terms of grams of absolute ethanol consumed per kilogram of body weight $(\mathrm{g} / \mathrm{kg}$ etoh): [(postinfusion body weight - preinfusion body weight $) \times($ ethanol solution $\%) \times(0.78) /$ (preinfusion body weight/1000)].

During the intake test on PDs 15 and 16, pups were videotaped for subsequent analysis of behaviors. Motor activity was evaluated as frequency of locomotion (moving of four limbs) and wall climbing. Behaviors were evaluated during the intake test through the following procedure (Fig. 1): 20 trials of $10 \mathrm{~s}$ each (a behavioral trial began every other infusion when a red light indicated that the solution was delivered); intertrial interval was 16s. In addition, each trial was subdivided in two intervals of 5 seconds. Trained observers blinded to treatments recorded the pup's behavior during each interval.

2.1.4. Data analysis-Maternal body weight changes during pregnancy were subjected to a two-way mixed analysis of variance (ANOVA) defined by gestational treatment and gestational day.

Maternal postnatal weights and preweanling's body weights on PD 15 were analyzed via ANOVAs that took into account gestational and postnatal drug treatments as independent variables, and whenever necessary, postnatal days was included as repeated measure.

Mixed analyses of variance were conducted to determine consumption patterns for Water or Ethanol solutions. The dependent variables were \% ML (Water or Ethanol infusions) and g/ $\mathrm{kg}$ etoh (Ethanol infusions). In order to avoid litter over representation, no more than two pups from a given litter were included in a particular treatment (one male and one female, whenever possible). Gender of pups failed to exert main effect and/or did not interact with the remaining factors under consideration. For this reason, the average intake scores corresponding to pups representative of the same litter and exposed to similar treatment during PD 15 served as the unit of analysis for consumption patterns. Each of the twentyfour groups defined by the corresponding factorial design (Prenatal treatment: EtOH1, EtOH2 or Water; Postnatal treatment: EtOH or Water; and Solution Infused: $5.0 \%$ or 10.0 $\% \mathrm{v} / \mathrm{v}$ ethanol concentrations or Water) was composed of 6-9 litter scores. Data from the intake test at PDs 15 and 16 served as repeated measures. Newman-Keuls' post-hoc tests were used to further analyze significant main effects or interactions.

Motor activity (locomotion and wall climbing) was examined with Non-parametric Analysis of Variance (Kruskal-Wallis, Info-Stat Free version 2007). Locomotion or wall-climbing scores of pups representative of the same litter and exposed to similar treatment during PD 15 served as the unit of analysis. The independent variables included Day of intake test and Pre- and Postnatal treatment. The frequencies of each behavior from each interval were combined (summated) to yield the total motor activity score considered as the dependent variable under analysis. 
For all statistical analysis the critical value for significance was $p<0.05$. More details are described in the Results section.

\subsection{Results}

2.2.1. Maternal body weights-Maternal weights during pregnancy were found to vary significantly as a function of gestational day $[F(3,147)=332.43, p<0.001]$. As could be expected body weights increased as a function of passage of time. Independent of the drug treatment, body weights during late pregnancy were as follows: GD 17, 338.2 $\pm 4.8 \mathrm{~g}$; GD $18,348.5 \pm 4.9 \mathrm{~g} ;$ GD 19, 359.6 $\pm 5.2 \mathrm{~g}$ and GD 20, $370.3 \pm 5.5 \mathrm{~g}$. For maternal body weight changes across postnatal days the corresponding ANOVA showed a significant main effect of day $[F(5,230)=9.5, p<0.01]$, confirming that dams progressively gained weight throughout the postnatal period. The following means, corresponding to the first, third and sixth days of postnatal treatment, illustrate the gradual increase in maternal body weights during the first two weeks of lactation: PD 3, 286.6 $\pm .4 .5 \mathrm{~g}$; PD 7, $292.5 \pm 4.0 \mathrm{~g}$ and PD13, $296.94 \pm 4.4 \mathrm{~g}$ (values have been collapsed across Prenatal and Postnatal drug treatments).

2.2.2. Preweanling ethanol consumption patterns-Preinfusion body weights at $\mathrm{PD}$ 15 were analyzed with a two-way ANOVA with Prenatal and Postnatal Treatment as factors. This analysis revealed a significant main effect of Prenatal and Postnatal Treatment $[F(2$, $143)=8.56, F(1,143)=5.33$, respectively, $p s<0.025]$. The interaction also achieved significance $[F(2,143)=10.40, p<0.01]$. All pups that suckled from a dam administered water or those pups exposed to a $1.0 \mathrm{~g} / \mathrm{kg}$ during late gestation and suckled from a dam subjected to a $2.5 \mathrm{~g} / \mathrm{kg}$ ethanol dose exhibited significantly higher body weight at PD 15 than pups that were exposed to water or to both a $2.0 \mathrm{~g} / \mathrm{kg}$ ethanol dose during gestation and ethanol during nursing.

Preweanling water consumption levels at PD 15 did not differ. Water consumption during both days of test was analyzed through a three-way mixed ANOVA defined by Prenatal Treatment, Postnatal Treatment and Day of evaluation. There were significant main effects of Day $[F(1,42)=4.17, p<0.05]$. Independently of Pre- and Postnatal Treatments, pups exhibited significantly higher consumption levels of water on PD 16 than on PD 15. This analysis failed to exhibit significant main effects or interactions as a function of Pre- and/or Postnatal Treatments (Table 1).

Separated ANOVAs were conducted to analyze preweanling ethanol intake values in terms of grams of absolute ethanol consumed per kilogram body weight This analysis was defined by Prenatal Treatment (Water, EtOH1 or EtOH2), Postnatal Treatment (Water or EtOH), Ethanol Solution infused (5.0\% or $10.0 \%$ ) and Day of evaluation (PDs 15 and 16) as factors. For ethanol consumption levels, the ANOVA showed significant main effects of Postnatal Treatment, Ethanol Solution and Day of evaluation $[F(1,89)=5.26, F(1,89)=$ $8.62 ; F(1,89)=4.68$, respectively; $p s<0.05$ ]. Significant interactions were observed between Prenatal Treatment, Postnatal Treatment and Solution of ethanol infused $[F(2,89)$ $=3.48, p<0.05]$ and among Prenatal and Postnatal Treatments and Day of evaluation $[F(2$, $89)=5.76, p<0.01]$.

In order to analyze the locus of significant effects corresponding to the triple interactions, sequential ANOVAs across concentration of the ethanol solution infused to the pups were conducted.

When pups were infused with a $5.0 \%$ ethanol solution during the first day of test (PD 15), the analysis for consumption levels (\% ML) showed a borderline main effect of Postnatal Treatment $[F(1,43)=3.98, p=0.052]$. When the variable under analysis was $\mathrm{g} / \mathrm{kg}$ intake this effect reached significance $[F(1,43)=5.47, p<0.025]$. Independently of Prenatal 
Treatment pups exposed to ethanol during the nursing period had greater $\mathrm{g} / \mathrm{kg}$ ethanol consumed than pups exposed to a sober dam during the same period (Fig. 2). In order to analyze consumption scores of a $5.0 \% \mathrm{v} / \mathrm{v}$ ethanol solution during PDs 15 and 16 the threeway ANOVA was defined by Prenatal, Postnatal Treatments and Day of evaluation. The analysis of consumption levels (\% ML) exhibited significant main effects of Postnatal Treatment and Day of evaluation $[F(1,43)=4.75, F(1,43)=8.46$, respectively; $p$ s $<0.05]$. The interaction between Prenatal, Postnatal Treatment and Day of test also achieved significance $[F(2,43)=5.88, p<0.01]$. Newman Keuls' post-hoc test indicated that during PD 16 those pups that received a $2.0 \mathrm{~g} / \mathrm{kg}$ ethanol dose during late gestation consumed significantly higher levels of ethanol independently of postnatal drug experience.

Nevertheless, those pups prenatally exposed to a $1.0 \mathrm{~g} / \mathrm{kg}$ ethanol dose only exhibited increases in ethanol consumption levels of a $5.0 \% \mathrm{v} / \mathrm{v}$ ethanol solution if they had the opportunity to suckle from an ethanol-intoxicated dam (Fig. 3). For g/kg etoh consumed of a $5.0 \% \mathrm{v} / \mathrm{v}$ ethanol solution, the analysis showed the same significant effects seen in terms of $\% \operatorname{ML}[F(1,43)=5.79, p<0.05 ; F(1,43)=9.49, p<0.01 ; \mathrm{F}(2,43)=4.81, p<0.025 ;$ respectively].

The analysis of consumption patterns when rats were evaluated with a $10.0 \% \mathrm{v} / \mathrm{v}$ ethanol solution failed to exhibit significant effects (Table 2).

\subsubsection{Behavioral evaluation of preweanling rats during intake test-When} preweanling rats were infused with water the analysis of motor activity as a function of Day of evaluation indicated that during PD 16 pups displayed more activity than during PD 15 $[H(1, n=90)=5.12, p<0.025]$; activity scores on PD 15 as a function of Pre- and Postnatal Treatment achieved significance $[H(5, n=45)=13.01, p<0.025]$. When compared with the control group (water-water), a posteriori comparison shown that pups exposed to ethanol during nursing displayed less motor activity (Fig. 4A), independently of prenatal treatment. Analysis of motor activity of preweanling rats on PD 16 indicated no significant effects of Pre- and Postnatal Treatment.

Analysis as a function of ethanol solutions ( 5.0 or $10.0 \% \mathrm{v} / \mathrm{v}$ ) indicated no significant effects on either PD 15 or PD 16. Statistical analysis when pups were infused with ethanol solutions as a function of Day also showed that rats exhibited significantly more activity on PD 16 than on PD $15[H(1, n=186)=5.32, p<0.025]$ (Fig. 4B, C). Activity scores analyzed as a function of Pre- and Postnatal Treatment indicated no significant effects on PD 15, but achieved significance on PD $16[H(5, n=93)=13.87, p<0.02]$. Pups exposed to ethanol during nursing and to the low ethanol dose during gestation (EtOH 1-EtOH) displayed lesser motor activity than the control group (water-water) when exposed to $5.0 \% \mathrm{v} / \mathrm{v}$ ethanol solution (Fig. 4B).

\section{Experiment 2a}

Given the fact that ethanol exposure during late gestation can affect neonatal ethanol metabolism [22] we conducted the present experiment to adequately design the next study $2 \mathrm{~b}$ (stereological analyses). The question was whether BECs, at the age at which cells were counted in the GCL of the MOB (Experiment 2b), would be affected by prenatal ethanol exposure. Neonatal BECs on PD 6 were evaluated as a function of gestational treatment $(0.0,1.0$ or $2.0 \mathrm{~g} / \mathrm{kg})$. The postnatal ethanol dose administered on PD6 was $1.5 \mathrm{~g} / \mathrm{kg}$.

\subsection{Materials and Methods}

3.1.1. Subjects-One hundred and twenty-seven pups representative of 23 litters were used. The housing conditions, animal care and maintenance were identical to those described in Experiment 1. 


\subsubsection{Drug treatments}

Prenatal Treatments: Maternal drug treatment from GD 17 to 20 was the same as Experiment 1. Experimental groups were defined by prenatal treatment. The number of dams assigned to each gestational treatment was as follows: Water, $n=8$; EtOH $1, n=8$; and $\mathrm{EtOH} 2, n=7$.

Neonatal Treatment: On PD 6 all pups were weighed and administered (i.g.) $0.015 \mathrm{ml} / \mathrm{g}$ of a $12.6 \% \mathrm{v} / \mathrm{v}$ ethanol solution (vehicle: room temperature tap water; ethanol dose: $1.5 \mathrm{~g} / \mathrm{kg}$ ). The intubation procedure was identical to that used in dams, except for employing a smaller polyethylene cannula (PE 10; Clay Adams, Parsippany, New Jersey, U.S.A.) attached to a disposable 1-ml syringe.

3.1.3. Determination of neonatal blood ethanol concentrations-On PD 6 pups were removed from the maternity cages one hour prior to i.g. administration. This was accomplished by placing the pups in a cage containing clean wood shavings and kept under temperature-controlled conditions through the use of adjustable heating pads (ambient temperature: $32{ }^{\circ} \mathrm{C}$ ). Sampling procedures took place $15,30,60,90$ or 120 min after ethanol was administered. In a given litter, one pup was assigned to each post-administration time. Pups were sacrificed in order to obtain blood samples ( $200 \mu \mathrm{l} / \mathrm{pup})$. Pup's blood samples were subjected to head-space gas chromatography analysis [48,49]. Each blood sample was fractioned in order to obtain two $100 \mu \mathrm{l}$ samples. These samples were then placed in microvials containing $20 \mu \mathrm{l}$ of a butanol solution $(51 \mathrm{mg} / \mathrm{dL})$ that served as an internal standard. The manipulation of the samples was performed in containers filled with crushed ice. Microvials were hermetically sealed and incubated in a water bath at $60^{\circ} \mathrm{C}$ for $30 \mathrm{~min}$. Gas-tight syringes (Hamilton, $10 \mu \mathrm{l}$ ) were used to collect the volatile component of the samples and to inject them into the gas chromatograph (Hewlett-Packard, Model 5890). Column (Carbowax $20 \mathrm{M} ; 10 \mathrm{~m} \times 0.53 \mathrm{~mm} \times 1.33 \mu \mathrm{m}$ film thickness), injector and detector temperatures were as follows: 60,150 , and $250{ }^{\circ} \mathrm{C}$, respectively. Nitrogen served as the carrier gas (flow rate: $15 \mathrm{ml} / \mathrm{min}$ ).

3.1.4. Data analysis-Maternal body weight changes during pregnancy were subjected to a mixed analysis of variance (ANOVA) defined by gestational treatment and gestational day. Pups' pre-administration body weights (PD 6) were analyzed via an ANOVA that included gestational drug treatment and post-administration time as orthogonal independent variables.

BECs were averaged across both samples obtained during each post-administration interval. All values were expressed as milligrams of ethanol per deciliter of blood $(\mathrm{mg} / \mathrm{dL})$. BECs were analyzed using a mixed ANOVA with prenatal group as the between subject factor and ethanol post-administration time $(5,15,30,60,90$ and $120 \mathrm{~min})$ as repeated measures.

\subsection{Results}

3.2.1. Maternal and neonatal body weights-Maternal body weight gained during late gestation and the pre-administration body weight of pups on PD 6 were not significantly affected by ethanol treatment during pregnancy.

3.2.2. Neonatal blood ethanol concentrations on PD 6-Pups' BECs were analyzed through a two-way ANOVA defined by Prenatal Treatment (Water - EtOH 1 - EtOH 2) and Post-administration sampling time (15, 30, 60, 90 and $120 \mathrm{~min})$. The analysis revealed significant main effects of post-administration time $[F(4,80)=5.92, p<0.01]$. The post-hoc test indicated that BECs reached the highest level at post-administration times 30 and 60 $\min ($ average $=110 \mathrm{mg} / \mathrm{dL}$ ). At $120 \mathrm{~min}$ BECs were significantly lower than at post- 
administration times 30, 60 and 90 min, but were not significantly different from postadministration time $15 \mathrm{~min}$. Of major importance for this experiment was the observation that pups' BECs were not affected by prenatal treatment. Prenatal treatment was not found to exert a significant main effect, or to significantly interact with post-administration time (Fig. 5).

\section{Experiment 2b}

Experiment 2a allowed us to know that prenatal treatments had no effect upon ethanol metabolism of pups at PD 6. It is worth mentioning that this result refers primarily to peripheral metabolism and we cannot rule out the possibility of differences in metabolism in the central nervous system (e.g. catalase system) $[88,89]$.

In the present experiment we estimated the number of cells in the GCL of the MOB of pups at PD 7, as a function of pre-and postnatal treatments with ethanol. Prenatal treatments were similar those described in Experiments 1 and 2a, except that, in the present experiment, dams were administered water or the highest ethanol dose, $2.0 \mathrm{~g} / \mathrm{kg}$. As in Exp. 2a, postnatal treatment was an i.g. administration of $1.5 \mathrm{~g} / \mathrm{kg}$ ethanol dose on PD 6. In addition, a control group was administered (i.g.) water.

Parameters of the current experiment were selected on the basis of the following factors: a) migration of the olfactory interneurons begins during late gestation in rodents [60]; b) these cells start to reach the GCL about a week after leaving subventricular zone (SVZ) [62]; c) the "brain growth spurt" period between PDs 4 to 9 has been described as particularly vulnerable to ethanol neurotoxicity [69-71]; and d) $1.5 \mathrm{~g} / \mathrm{kg}$ ethanol dose was selected on the basis of preliminary studies indicating that this dose results in neonatal peak BEC similar than the found in fetal blood when dams are administered $2.0 \mathrm{~g} / \mathrm{kg}$ during late gestation $(\approx$ $130 \mathrm{mg} \%)$.

\subsection{Materials and Methods}

4.1.1. Subjects-Seventeen pups representative of 10 litters were used. The housing conditions, animal care and maintenance were identical to those described in Experiment 1.

\subsubsection{Drug treatments}

Prenatal Treatments: Dams were administered (i.g.) 0.0 or $2.0 \mathrm{~g} / \mathrm{kg}$ ethanol dose from GD 17 to 20 in a manner similar to that for dams in Exp. 1 and 2a.

Neonatal Treatment: On PD 6 pups representative of each prenatal treatment were weighed and administered (i.g.) $0.015 \mathrm{ml} / \mathrm{g}$ of a $12.6 \% \mathrm{v} / \mathrm{v}$ ethanol solution (vehicle: room temperature tap water; ethanol dose: $1.5 \mathrm{~g} / \mathrm{kg}$; Postnatal EtOH Group) or Water (Postnatal Water Group). On PD 6, pups were removed from the maternity cages one hour prior to i.g. administration. This was accomplished by placing the pups in a cage containing clean wood shaving and kept under temperature-controlled conditions through the use of adjustable heating pads (ambient temperature: $32{ }^{\circ} \mathrm{C}$ ). Two hours after i.g. administration pups were returned to the home cage. Manipulations done for i.g. intubations were the same as those utilized in Experiment 2a. Experimental groups were defined by prenatal treatment (Water or EtOH 2) and postnatal i.g. administration on PD 6 (Water or EtOH). The number of pups assigned to each experimental group was as follows: Water-Water, $n=4$; Water-EtOH, $n=5$; EtOH 2-Water, $n=4$; EtOH 2-EtOH, $n=4$. 


\subsubsection{Histology}

Perfusion and Fixation: On PD 7 (twenty four hours after i.g. administration) pups were anesthetized with an intraperitoneal (i.p.) administration of $30 \%$ chloral hydrate solution (dose: $0.1 \mathrm{ml} / 100 \mathrm{~g}$ ), and were perfused via the left cardiac ventricle with a saline solution $(0.9 \%$ o) followed by $4 \%$ paraformaldehyde in PBS, $\mathrm{pH}$ 7.4. Brains remained in the skulls for $24 \mathrm{~h}$ at $4{ }^{\circ} \mathrm{C}$, then were removed and placed in $30 \%$ sucrose solution for storage at $8^{\circ} \mathrm{C}$ or for immediate sectioning.

Sectioning and mounting: Each right olfactory bulb (OB) was cut from the brain and embedded in Cryoplast (Sistemas Analiticos SA) in order to place it in a Cryostate (Minitome, International Equipment Company-Division of Damon). Parallel coronal sections (16 $\mu \mathrm{m}$ thick sections) were cut throughout the entire olfactory bulb. In order to prepare each OB for stereological analysis (see below), every 10th section was collected for sampling. The sections were directly mounted onto gelatin-coated slides and immediately stored at $-20^{\circ} \mathrm{C}$ until staining.

Staining: The mounted sections were dried at $60^{\circ} \mathrm{C}$ prior to staining and hydrated in a series of ethanol solutions. Slides were then incubated in Cresyl Violet $(0.5 \%$ without acetic acid) for $30 \mathrm{sec}$, dehydrated through a series of graded ethanol solutions, cleared in xylene and placed under a coverslip with DPX (Fluka).

\subsubsection{Stereological analysis}

General: The total number of cells in the GCL of each right MOB was estimated with a modified procedure of the original optical fractionator technique [90-92]. In accord with this technique, the estimates were based on number of cells counted with optical dissectors in a known fraction of the volume of each GCL. This was achieved by counting the cells in a known fraction of the thickness of a section, under a known fraction of the sectional area of the layer in each mounted section, on a known fraction of the sections that passed through the olfactory bulb. A sampling scheme was designed so all parts in GCL had an equal opportunity of being sampled with optical dissectors.

Anatomical definition of the GCL in the MOB: GCL was defined as including an internal GCL and the thin internal plexiform layer boundary by the distinctly mitral cell layer (Fig. 6A) [76].

Image capture: For the stereological analysis, a photo of each mounted section from the OB was taken (Fig. 6B). Images from GCL were captured with an Olympus C7070 camera attached to an Olympus microscope with a 10x objective lens.

\section{Sampling scheme}

Sections: A systematic random sample of the sections in the series from each right OB was used in the analysis. Cells were estimated from approximately 22 sections that were selected at equally spaced intervals along the entire OB. This was achieved by mounting every 10th section from the bulb, after randomly selecting the first section within the first interval. The section sampling fraction (ssf) was consequently $1 / 10$. Additionally the total numbers of sections obtained from each OB were registered as an indirect measure of bulb size. For all analyses the posterior limit of each bulb was defined as the last section in which olfactory glomeruli appeared [93].

Sectional area: In accord with Gundersen's rules [94], in each section occupied by the GCL the sampling scheme was made in a systematic random mode. This was achieved by positioning an unbiased counting frame of known area superimposed on the photographic 
image of the section (Fig. 6A). The counting frame grid was generating through draw software (CorelDraw 12.0). Each optical dissector is a square equidistant from the other three that delimited an area in which dimensions are equal to 100 squares. As a result, the dissector allows counting of $1 \%$ of the total area (Fig. 6B). In case of border cells, each dissector has two borders of cell inclusion and two of exclusion (Fig. 6C). Consequently, the area sampling fraction (asf) was 1/100.

Section thickness: Thickness of each section obtained with the cryostat was originally 16 $\mu \mathrm{m}$ and each section allowed capture of a unique image focus when the photograph was taken. The whole thickness of each section was considered in the analysis, so the thickness sampling fraction (tsf) was $1 / 1$. The dimension of the section depth chosen to analyze cell number was similar to that used in comparable published studies in which optical fractionator technique was applied with computer-controlled systems [76,92]. In those studies the fraction of thick section sampled was $12-15 \mu \mathrm{m}$ because of the estimated cell nucleus diameter that would typically be sampled in each counting frame.

Counting: Based on the optical and physical dissector counting rules [95-98], staining cells that come into focus in an optical dissector were counted. Borders to include or exclude cells were taken into account. The total number of cells counted in a section was named as $Q^{-}$.

Estimates of total number: The number $(N)$ of cells in the GCL of each right MOB was estimated as the product of the number of cells counted with the optical dissectors $\left(\Sigma Q^{-}\right)$, and the reciprocals of the fraction of sections sampled (ssf), the fraction of the sectional area sampled (asf), and the fraction of the section thickness sampled (tsf) [92]: $N=\Sigma Q^{-} \cdot 1 /$ ssf . $1 /$ asf $\cdot 1 /$ tsf

Precision of the estimates: The sampling scheme was evaluated in terms of the coefficients of error (CEs) of the individual estimates $\Sigma Q^{-}$(one per MOB). On the basis of similar analyses in the olfactory bulb [76] it was decided a priori that the $\mathrm{CE}\left(\Sigma Q^{-}\right)$could be less than $5 \%(<0.05)$. This coefficient is simply a means to assess the likelihood of reproducibility of results in view of the degree of methodological precision applied. It has no biological significance $[91,92,99]$. The simple rule is that if CE associated with the olfactory bulb is higher than $5 \%$, it must not be included for the analysis. The individual CEs were calculated with the following quadratic approximation formula [91,92,99]: $\mathrm{CE}\left(\Sigma Q^{\top}\right)=$ $(\sqrt{T}$ otal Variance $) / \Sigma Q^{-}$

In this formula, the total variance was calculated from the sum of the variance due to sampling within sections -- i.e. the Nugget Variance and that due to sampling between sections, i.e. that which arises from the systematic random sampling of the section series, the SRS variance $[92,99]$.

4.1.5. Data analysis-Maternal body weight changes during pregnancy were subjected to a mixed analysis of variance (ANOVA) defined by gestational treatment and gestational day. Neonate body weights on PDs 6 and 7 were analyzed via ANOVAs that took into account gestational drug treatments and i.g administration.

The numbers of sections obtained from OB and the estimates of the number of granular cells $(N)$ of pups on PD 7 were examined with Non Parametric Analysis of Variance (KruskalWallis, Info-Stat Free version 2007) defined by Prenatal Treatment and i.g. administration on PD 6. 


\subsection{Results}

4.2.1. Maternal and neonatal body weights-Maternal body weight gained during late gestation and the pre-administration body weight of pups on PD 6 were not significantly affected by ethanol treatment during pregnancy. On PD 7 ( $24 \mathrm{~h}$ post-administration) body weight of neonates was not affected by either ethanol treatment during pregnancy or i.g. administration on the previous day.

\subsubsection{Stereological analysis}

Precision of estimates: Each individual estimator generated CEs $<0.05$, so all olfactory bulbs were included in the statistical analysis.

Cell number in the GCL: The estimates of the number of cells $(N)$ on PD 7 as a function of previous treatments are shown in Table 3. The Kruskal-Wallis analysis defined by Prenatal Treatment and i.g. administration on PD 6 showed that treatments exerted no significant effects on number of cells in the granular layer $[H(3, n=17)=2.39, p=0.49]$. When the statistical analysis of cell number included only a single independent variable, neither Prenatal treatment nor Postnatal i.g. administration exerted significant effects $[H(1, n=17)=$ $3.34, p=0.23 ; H(1, n=17)=1.33, p=0.60$, respectively].

Number of sections obtained from the OB: Analysis of the total number of sections obtained from the entire OB (Table 3) yielded results similar to the above analysis of cell number in the GCL of the MOB. The statistics are as follow: a) Prenatal Treatment and Postnatal i.g. administration: $H(3, n=17)=5.83, p=0.08$; b) Prenatal treatment: $H(1, n=$ 17) $=1.22, p=0.13$; c) Postnatal i.g. administration: $H(1, n=17)=3.00, p=0.14$.

\section{Discussion}

The present results show that the postnatal increase in acceptance of ethanol associated with prenatal exposure to low or moderate ethanol doses, does not coexist with teratogenic effects of ethanol on the main olfactory bulb. Experiment 1 indicated that, during late gestation or early postnatal life, rats can detect and retain information about ethanol that modulates later ingestive responsiveness to the drug, and this effect appears to be enhanced when both fetal and postnatal experiences occur in sequence.

On PD 16 (Exp. 1), preweanlings had greater intake of a $5.0 \%$ ethanol solution if they had been given a single dose of $2.0 \mathrm{~g} / \mathrm{kg}$ ethanol on each of GD17-20. In a previous study [27] we did not find effect of this same prenatal treatment when pups were tested for intake of the relatively weak ethanol concentration $(0.22 \% \mathrm{v} / \mathrm{v})$ known to occur in maternal milk after the same subnarcoleptic ethanol dose given to dams postnatally with the present study. Heightened intake of a weak ethanol concentration $(0.22 \mathrm{~g} / \mathrm{kg} \mathrm{v} / \mathrm{v})$ only appeared evident when pups were exposed to ethanol during pre-and postnatal period, apparently by recruiting ethanol's chemosensory attributes during intake test [27]. In Exp. 1 the solution of $5.0 \% \mathrm{v} / \mathrm{v}$ ethanol could recruit sensory information, but pharmacological effects of the drug also could be perceived by pups following consumption [100]. Increases in ethanol consumption at PD 16 could be explained by memory reactivation processes occurring during the intake test on PD 15 initiated by the sensory context of ethanol in the prenatal womb, and might also contribute to direct reinforcing effects. These results of the second day of testing are in agreement with a previous study [24].

After animals have been exposed to ethanol in utero, changes in subsequent responses to the drug could be determined by prenatal exposure to ethanol's sensory attributes or by the association between this sensory cue and ethanol's postabsortive effects $[19,29,33,34]$. In 
several mammal species, it has been demonstrated that prenatal experience with artificial odors or cues derived from maternal diet determine long-lasting effects upon later behavioral responsiveness to these stimuli [7-12]. At present, experimental evidence supports the hypothesis that ethanol exposure during late gestation generates appetitive conditioning mediated perhaps by an acquired association between the chemosensory properties of ethanol and its pharmacologically reinforcing effects involving the release of endogenous opioid [28-30]. Consequently, the increase in ethanol consumption demonstrated in the present and previous studies [24,25] after pups are prenatally exposed to the drug, could be a conditioned response with a positive motivational value [29].

In Experiment 1 pups exposed to ethanol during postnatal nursing increased their intake of a $5.0 \% \mathrm{v} / \mathrm{v}$ ethanol solution, independently of prenatal treatment. A previous study described a similarly enhanced intake of ethanol among preweanlings and adolescents exposed to ethanol during nursing [44]. This latter result [44] was explained as a negative reinforcing (anxyolitic) event in view of evidence that pups in these nursing circumstances generate an aversive association to chemosensory attributes of ethanol due perhaps to the deleterious pharmacological effects of the drug upon maternal care [40,49]. In subsequent studies $[27,48]$ we found that ethanol-related disruption of maternal behavior is attenuated when females are also given ethanol during late gestation, suggesting the development of behavioral tolerance. Accordingly, the present enhancement of ethanol intake on PD 15 cannot be directly linked with altered maternal care because this effect occurred whether or not the dams were given ethanol during gestation as well as during nursing $[27,48]$.

We therefore suggest that the enhanced ethanol intake observed at PD 15 in the present experiment could be explained as an effect of basic pre-exposure (familiarization) to the stimulus, given that all pups perceived ethanol chemosensory cues in the nursing context. Several studies have demonstrated that infantile familiarization with ethanol odor promotes olfactory preferences for the drug and heightened ethanol consumption [101-104]. Alternatively, pups could have undergone appetitive conditioning to ethanol cues during lactation. Maternal presence or the action of suckling [82,104] could be operating as a source of positive reinforcement that becomes associated with ethanol flavor of the dam's milk. Considering all of these diverse explanations, we are not able to discard the possibility that any of several mechanisms of learning might be involved in the present results. This implies the possibility that ethanol-related memories established by ethanol exposure during nursing differ in their motivational values depending on the quality of maternal care.

Although prenatal ethanol exposure with the $2.0 \mathrm{~g} / \mathrm{kg}$ dose increased consumption of a 5.0 $\% \mathrm{v} / \mathrm{v}$ ethanol solution independently of ethanol during nursing, prenatal exposure to the lower ethanol dose $(1.0 \mathrm{~g} / \mathrm{kg})$ alone did not generate the same effect. When this prenatal exposure was combined with postnatal ethanol exposure, through lactation, however, pups showed increases in their intake of a $5.0 \% \mathrm{v} / \mathrm{v}$ ethanol solution at PD 16. In the context of the appetitive conditioned response hypothesis [28,29] our results on PD 16 suggest that pups prenatally exposed to the lower ethanol dose require re-exposure to ethanol during nursing, and perhaps also at the test on PD 15, to reactivate ethanol-related memories. An alternative hypothesis is that pups learn to recognize ethanol due to gestational pre-exposure to its chemosensory characteristics and, with the lower prenatal dose, subsequent postnatal experience with ethanol operates as a critical factor in the persistence of these early memories. Previous [27,48] and present evidence about interaction between pre- and postnatal ethanol experience lead to the general conclusion that the increased resistance to ethanol's disruption of maternal care created by the dam's prenatal exposure to ethanol is a general reflection of facilitated social and/or nutritional transmission of ethanol-related cues, that results from interaction within the pup-dam dyad. 
In Exp. 1 none of the ethanol treatments tested had an effect on intake of the $10 \% \mathrm{v} / \mathrm{v}$ ethanol solution. This high ethanol concentrated solution could generate orosensory aversion that possibly will disguise early generated memories related to ethanol. Previous experience with ethanol, as with many olfactory and gustatory stimuli, may enhance the pups' ability to discriminate and otherwise process them during infancy [105]. This effect seems to occur related to $5.0 \% \mathrm{v} / \mathrm{v}$ ethanol solution intake as has been show in prior study where a brief pre-exposure to similar ethanol concentration turn orosensory aversive response in appetitive reinforcing effects [100]. These results in intake test, in addition with the results describing differences between gestational treatments ( 1.0 or $2.0 \mathrm{~g} / \mathrm{kg}$ ), suggest limitations on the generation of ethanol-related memories, and/or in memory retrieval processes just as generalized responses.

Results of the pups' activity during the intake test allow us to discount neurobehavioral alterations in motor behavior that could seem directly associated with the intake patterns we observed. Some prior studies, evaluating overall locomotion, arrived to similar conclusions in view of no indications of ethanol-mediated conditioned motor responses [106,107]. This is notable in view of evidence linking fetal ethanol-related motor disorders in utero with postnatal use or abuse of the drug [78,108-110]. Reductions on motor activity that we observed in EtOH1-EtOH group during 5.0\% v/v infusion appear analogous to prior described decreased activity in neonates when are re-exposed to ethanol stimulus perceived in utero [111].

As possible neural substrates underlying the generation of early ethanol-related memories, olfactory and reinforcement pathways should be proposed. First, neural pathways identify to trigger olfactory learning in adults are immature in neonates or infants [112-114]. However, the olfactory bulb, the noradrenergic locus coeruleus and the anterior piriform cortex has been proposed as the key areas that participate in olfactory learning process in the developing organism with the opioid system modulating olfactory preferences [114-116]. Second, ethanol reinforcement effects appear to induce increases in extracellular concentration of dopamine (DA) in the nucleus accumbens (NA) that depends on either, direct activation of opioid receptors in NA or indirect opioidergic control from ventral tegmental area [117]. As was earlier described, the endogenous opioid system is involved in the acquisition of prenatal ethanol memories [29,30]. Since an ethanol-related memory involves chemosensory and pharmacological attributes of the drug, the affective value of the context in which early learning experiences occur could regulate the storage and expression of these memories later in development [33,118,119].

Results from Experiment 2a suggest that ethanol treatment during gestation (0.0, 1.0 or 2.0 $\mathrm{g} / \mathrm{kg}$ ) did not interfere with postnatal drug metabolism of ethanol, at least on PD 6 when pups were administered $1.5 \mathrm{~g} / \mathrm{kg}$ ethanol. This experiment also confirms unpublished results showing that BECs after given $2.0 \mathrm{~g} / \mathrm{kg}$ ethanol i.g. soon after birth were similar to those encountered in fetal blood, when the pregnant dam had been given $2.0 \mathrm{~g} / \mathrm{kg}$ ethanol i.g. [23].

According to Experiment 2b, ethanol administration during late gestation and/or PD 6 did not significantly affect cell number in the GCL of the MOB of rats on PD 7. It is notable that the average number of GCs in the MOB of control animals $\left(2.60 \times 10^{6}\right)$ was similar to those reported for preweanling rats in other studies [76,77]. Analysis of an indirect measure of olfactory bulb size (number of sections) also indicated no effect from the ethanol treatment.

As mentioned in the introduction section, GABAergic interneurons begin migration to the MOB during late gestation and thereafter undergo continuous neurogenesis throughout adult life [55,59-61]. Due to these characteristics, and that rats were exposed to ethanol during late gestation as well as one day prior to histological analysis, various neurodevelopment 
events might be affected. Since neuroblasts take 1-3 weeks to reach MOB from SVZ [62], missing cells should be evident in the analysis on PD 7 if ethanol exposure during fetal life disrupts proliferation and migration processes. However, we cannot discard the possibility that ethanol effects during late gestation could be alleviated by newborn cells generated by neurogenesis processes during the postnatal period before ethanol postnatal treatment at PD $6[120,121]$.

Related to the possibility that ethanol disrupts migration process, a study in vitro using low and moderate ethanol doses reported a reduction in the velocity of migration of GCs from mouse cerebellum [72]. On the other hand, we have conducted similar in vitro experiments and when precursors of MOB interneuron were exposed to moderate ethanol dose (equivalent to $2.0 \mathrm{~g} / \mathrm{kg}$ ) in vitro we have not found disruption of cell migration [122].

An additional hypothesis to explain the absence of effects of gestational drug exposure upon GCs number arises from evidence that early olfactory experience can regulate number of newborn GCs (by increasing recruitment or decreasing cell mortality) in the MOB of rodents during early development [52,123]. Given that ethanol has sensory characteristics (olfactory, taste, and trigeminal stimulation) as well as toxic effects [124-126], loss of cells could be masked by modulation of GCs number due to olfactory experience.

It seems unlikely that the single $1.5 \mathrm{~g} / \mathrm{kg}$ ethanol administration on PD 6 produced significant cell death, because results on PD 7 indicated no differences in GCs number compared with water-exposed pups. Some studies suggest it is possible that ethanol produces neural apoptosis following a single ethanol postnatal exposure in the developing brain of rodents $24 \mathrm{~h}$ after administration [127,128]. Given that stereological analyses was conducted $24 \mathrm{~h}$ after ethanol administration, we cannot address the possibility of replacement following cell death as an explanation of the null effects of postnatal ethanol administration.

We have found no published tests of the effects of low or moderate ethanol doses on the population of GCs in the MOB. Stereological studies indicated that GCs number is reduced as a function of heavy postnatal ethanol exposure $(6.6 \mathrm{~g} / \mathrm{kg})$ [76]. However, a subsequent study using $5.0 \mathrm{~g} / \mathrm{kg}$ ethanol found no effect of either gestational or postnatal exposures on cell number in GCL [77]. This last study did find significant effects on mitral cell population, and granular and Purkinje cells in cerebellum. This study [77] and the above in vitro experiments [72,122] raise an additional important issue: the vulnerability of this cell population to ethanol effects. As a whole, these studies suggest a lower vulnerability to ethanol effects in GCs within the MOB than in other locations in brain, such as cerebellum.

The present work and a previous study from our laboratory [27] seem to be rare in considering the interaction between pre- and postnatal experiences with relatively light ethanol doses -- doses representative of human ethanol intake, and also known to be capable of generating ethanol-related memories that can determine ethanol responsiveness later in development. This early learning about ethanol seems to consist of modified sensory experiences or acquired associations between ethanol's sensory properties and postabsorptive effects of the drug. No teratological effects of ethanol on GCL of the MOB have seemed to have a significant effect in these cases, perhaps because during these early stages GCs are already sufficiently functional to participate in processes required for the generation and consolidation of olfactory memories. Recently some studies have demonstrated that fetal chronic ethanol exposure tuned the neurophysiologic response of the olfactory epithelium to ethanol odor during early postnatal period and that predicted response is in accord with ethanol intake patterns [129-131]. Although these studies employed a higher ethanol concentration as well as a chronic schedule of exposure during 
gestation, we are not entitled to rule out the possibility of some similar neurophysiologic outcome in our model of ethanol prenatal exposure. Furthermore, since ethanol intake appears to be modulated by various neurotransmitters as opioids, dopamine and GABA [132-135] we can not discard the possibility that some disruption of the normal modulation of some neurotransmitters systems underlie the ethanol intake profiles shown in our experiments, beyond learning-related changes. In fact, some studies shown that moderate fetal ethanol exposure could induce direct or indirect changes upon several of the neurotransmitters systems that have been linked to ethanol consumption [136-138].

The general lesson of the present study seems to be that modulation of ethanol ingestion by prior ethanol experiences during early ontogeny does not necessarily depend on conventional teratological consequences of ethanol. Moreover, the present study adds to a growing body of results emphasizing that there are no "safe" doses of ethanol consumption during the gestational and early postnatal periods.

\section{Acknowledgments}

This research was supported by grants from ANPCyT (PICT 254, JCM and 14708, RAR), the NIAAA (AA11960, AA015992, and AA013098), the NIMH (MH035219) (NES), the CONICET (PIP 5116), the SECYT-UNC (159/09,) the MINCYT-Cba (PID 121/08) (RAR) and a fellowship from CONICET (to M.P.). The authors wish to express their gratitude to BO Haymal, NL Battiato, N Unsain and RS Miranda for their technical assistance.

\section{References}

1. Coppola, DM. The role of the main and accessory olfactory systems in prenatal olfaction. In: Marchlewska-Koj, A.; Lepri, JJ.; Muller-Schwarze, D., editors. Chemical Signals in Vertebrates. New York: Plenum Press; 2001. p. 189-96.

2. Pedersen PE, Bless EM. Prenatal and postpartum determinants of the 1st suckling episode in albino rats. Dev Psychobiology. 1982; 15:349-55.

3. Bless EM, Teacher MH. Suckling. Science. 1980; 210:15-22. [PubMed: 6997992]

4. Doty RL. Odor-guided behavior in mammals. Experientia. 1986; 15:257-71. [PubMed: 3514263]

5. Galef BG Jr. Weaning from mother's milk to solid foods. The developmental psychobiology of selfselection of foods by rats. Ann NY Acad Sci. 1992; 662:37-52. [PubMed: 1456638]

6. Schaal B, Hummel T, Soussignan R. Olfaction in the fetal and premature infant: functional status and clinical implications. Clin Perinatol. 2004; 31:261-85. [PubMed: 15289032]

7. Bilko A, Altbäcker V, Hudson R. Transmission of food preference in the rabbit: the means of information transfer. Physiol Behav. 1994; 56:907-12. [PubMed: 7824590]

8. Hepper PG. Adaptative fetal learning: prenatal exposure to garlic affects postnatal preferences. Anim Behav. 1988; 36:935-36.

9. Schaal B, Marlier L, Soussignan R. Responsiveness to the odour of amniotic fluid in the human neonate. Biol Neonate. 1995; 67:397-406. [PubMed: 7578623]

10. Schaal B, Marlier L, Soussignan R. Human fetuses learn odors from their pregnant mother's diet. Chem Senses. 2000; 25:729-37. [PubMed: 11114151]

11. Semke E, Distel H, Hudson R. Specific enhancement of olfactory receptor sensitivity associated with fetal learning of food odors in the rabbit. Naturwissenschaften. 1995; 82:148-49. [PubMed: 7723852]

12. Smotherman WP. In utero chemosensory experience alters taste preferences and corticosterone responsiveness. Behav Neural Biol. 1982; 36:61-8. [PubMed: 7168731]

13. Ronca AE, Alberts JR. Sensory stimuli associated with gestation and parturition evoked cardiac and behavioral responses in fetal rats. Dev Psychobiology. 1994; 22:270-82.

14. Smotherman WP, Robinson SR. Rat fetuses respond to chemical stimuli in gas phase. Physiol Behav. 1990; 47:863-68. [PubMed: 2388943]

15. Smotherman WP, Robinson SR. The amniotic sac as scaffolding: prenatal ontogeny of an action pattern. Dev Psychobiology. 1991; 24:463-85. 
16. Coppola DM, Budde J, Millar L. The vomeronasal duct has a protracted postnatal development in the mouse. J Morphol. 2005; 218:59-64. [PubMed: 8230236]

17. Ronca AE, Alberts JR. Sensory stimuli associated with gestation and parturition evoked cardiac and behavioral responses in fetal rats. Dev Psychobiology. 1994; 22:270-82.

18. Schaal B, Marlier L, Soussignan R. Olfactory function in the human fetus: evidence from selective neonatal responsiveness to the odor of amniotic fluid. Behav Neurosci. 1998; 112:1438-49. [PubMed: 9926826]

19. Abate P, Pepino MY, Domínguez HD, Spear NE, Molina JC. Fetal associative learning mediated through maternal alcohol administration. Alcohol Clin Exp Res. 2000; 24:39-47. [PubMed: 10656191]

20. Chotro MG, Molina JC. Acute ethanol contamination of the amniotic fluid during gestational day 21: Postnatal changes in alcohol responsiveness in rats. Develop Psychobiology. 1990; 23:535-47.

21. Molina, JC.; Chotro, MG.; Domínguez, HD. Fetal alcohol learning derived from ethanol contamination of the prenatal environment. In: Lecanuet, JP.; Fifer, WP.; Krasnegor, NA.; Smotherman, WP., editors. Fetal development: A psychobiological perspective. Hillsdale, New Jersey: Lawrence Erlbaum Associates; 1995. p. 295-315.

22. Nizhnikov ME, Molina JC, Varlinskaya EI, Spear NE. Prenatal ethanol increases postnatal ethanol reinforcement. Alcohol Clin Exp Res. 2006; 30:34-45. [PubMed: 16433730]

23. Domínguez HD, López MF, Chotro MG, Molina JC. Perinatal responsiveness to alcohol's chemosensory cues as a function of prenatal alcohol administration during gestational days 17-20 in the rat. Neurobiol Learn Mem. 1996; 65:103-12. [PubMed: 8833099]

24. Arias C, Chotro MG. Increased palatability of ethanol after prenatal ethanol exposure is mediated by the opioid system. Pharmacol Biochem Behav. 2005; 82:434-42. [PubMed: 16257045]

25. Domínguez HD, López MF, Molina JC. Neonatal responsiveness to alcohol odor and infant alcohol intake as a function of alcohol experience during late gestation. Alcohol. 1998; 16:109117. [PubMed: 9665312]

26. Dominguez HD, Lopez MF, Molina JC. Interactions between perinatal and neonatal associative learning defined by contiguous olfactory and tactile stimulation. Neurobiol Learn Mem. 1999; 71:272-88. [PubMed: 10196106]

27. Pueta M, Abate P, Spear NE, Molina JC. Interaction between pre- and early postnatal alcoholrelated memories: Impact upon alcohol acceptance patterns. Int J Comp Psychol. 2005; 18:207-24.

28. Arias C, Chotro MG. Increased preference for ethanol in the infant rat after prenatal ethanol exposure, expressed on intake and taste reactivity tests. Alcohol Clin Exp Res. 2005; 29:337-46. [PubMed: 15770108]

29. Chotro MG, Arias C. Prenatal exposure to ethanol increases ethanol consumption: a conditioned response? Alcohol. 2003; 30:19-28. [PubMed: 12878271]

30. Miranda Morales RS, Molina JC, Spear NE, Abate P. Participation of the endogenous opioid system in the acquisition of a prenatal ethanol-related memory: effects on neonatal and preweanling responsiveness to ethanol. Physiol Behav. 2010; 101:153-60. [PubMed: 20451537]

31. Goodlett CR, Horn KH, Zhou FC. Alcohol teratogenesis: mechanisms of damage and strategies for intervention. Exp Biol Med (Maywood). 2005; 230:394-06. [PubMed: 15956769]

32. Faas AE, Spontón ED, Moya PR, Molina JC. Differential responsiveness to alcohol odor in human neonates: effects of maternal consumption during gestation. Alcohol. 2000; 22:7-17. [PubMed: 11109023]

33. Abate P, Pueta M, Spear NE, Molina JC. Fetal learning about ethanol and later ethanol responsiveness: Evidence against "safe" amounts of prenatal exposure. Exp Biol Med (Maywood). 2008; 233:139-54. [PubMed: 18222969]

34. Abate P, Spear NE, Molina JC. Fetal and infantile alcohol-mediated associative learning in the rat. Alcohol Clin Exp Res. 2001; 25:989-98. [PubMed: 11505023]

35. Abate P, Varlinskaya EI, Cheslock SJ, Spear NE, Molina JC. Neonatal activation of alcohol-relate prenatal memories: Impact upon the first suckling response. Alcohol Clin Exp Res. 2002; 26:1512-22. [PubMed: 12394284]

36. Molina, JC.; Dominguez, HD.; López, MF.; Pepino, MY.; Faas, AE. The role of fetal and infantile experience with alcohol in later recognition and acceptance patterns of the drug. In: Spear, NE.; 
Spear, LP.; Hanningan, JH.; Goodlett, C., editors. Alcohol and Alcoholism: Brain and Development. Hillsdale, NJ: Lawrence Erlbaum Associates; 1999. p. 119-228.

37. Chotro MG, Arias C, Laviola G. Increased ethanol intake after prenatal ethanol exposure: studies with animals. Neurosci Biobehav Rev. 2007; 31:181-91. [PubMed: 17010438]

38. Mennella JA, Beauchamp GK. The transfer of alcohol to human milk. Effects on flavor and the infant's behavior. N Engl J Med. 1991; 325:981-5. [PubMed: 1886634]

39. Pepino MY, Kraebel KS, López MF, Spear NE, Molina JC. Behavioral detection of low concentrations of ethanol in the preweanling rat. Alcohol. 1998; 15:337-53. [PubMed: 9590520]

40. Molina JC, Pepino MY, Johnson J, Spear NE. The infant rat learns about alcohol through interaction with an intoxicated mother. Alcohol Clin Exp Res. 2000; 24:428-37. [PubMed: 10798578]

41. Molina JC, Spear NE, Spear LP, Mennella JA, Lewis MJ. Alcohol and development: Beyond Fetal Alcohol Syndrome. Dev Psychobiology. 2007; 49:227-42.

42. Mennella JA. Infant's suckling responses to the flavor of alcohol in mother's milk. Alcohol Clin Exp Res. 1997; 21:581-5. [PubMed: 9194908]

43. Pepino MY, López MF, Spear NE, Molina JC. Infant rats respond differently to alcohol after nursing from an alcohol-intoxicated dam. Alcohol. 1999; 18:189-01. [PubMed: 10456571]

44. Pepino MY, Abate P, Spear NE, Molina JC. Heightened ethanol intake in infant and adolescent rats after nursing experiences with an ethanol-intoxicated dam. Alcohol Clin Exp Res. 2004; 28:895-905. [PubMed: 15201632]

45. Ponce LF, Pautassi RM, Spear NE, Molina JC. Nursing from an ethanol-intoxicated dam induces short- and long-term disruptions in motor performance and enhances later self-administration of the drug. Alcohol Clin Exp Res. 2004; 28:1039-50. [PubMed: 15252290]

46. Pepino MY, Spear NE, Molina JC. Nursing experiences with an alcohol intoxicated dam counteract appetitive conditioned responses toward alcohol. Alcohol Clin Exp Res. 2001; 25:1824. [PubMed: 11198710]

47. Chotro MG, Kraebel KS, McKinzie DL, Molina JC, Spear NE. Prenatal and postpartum alcohol exposure influences preweanling rat behavioral and autonomic responding to alcohol odor. Alcohol. 1996; 13:377-85. [PubMed: 8836327]

48. Pueta M, Abate P, Haymal OB, Spear NE, Molina JC. Ethanol exposure during late gestation and nursing in the rat: effects upon maternal care, ethanol metabolism and infantile milk intake. Pharmacol Biochem Behav. 2008; 91:21-31. [PubMed: 18602418]

49. Pepino MY, Abate P, Spear NE, Molina JC. Disruption of maternal behavior by alcohol intoxication in the lactating rat: a behavioral and metabolic analysis. Alcohol Clin Exp Res. 2002; 26:1205-14. [PubMed: 12198395]

50. Mori K, Nagao H, Yoshihara Y. The olfactory bulb: coding and processing of odor molecule information. Science. 1999; 286:711-5. [PubMed: 10531048]

51. Brennan PA, Keverne EB. Neural mechanisms of mammalian olfactory learning. Prog Neurobiol. 1997; 51:457-81. [PubMed: 9106902]

52. Lemasson M, Saghatelyan A, Olivo-Marin JC, Lledo PM. Neonatal and adult neurogenesis provide two distinct populations of newborn neurons to the mouse olfactory bulb. J Neurosci. 2005; 25:6816-25. [PubMed: 16033891]

53. Lledo PM, Gheusi G. Olfactory processing in a changing brain. NeuroReport. 2003; 14:1655-63. [PubMed: 14512833]

54. Lledo PM, Gheusi G, Vincent JD. Information processing in the mammalian olfactory system. Physiol Rev. 2005; 85:281-317. [PubMed: 15618482]

55. Bayer SA. 3H-thymidine-radiographic studies of neurogenesis in the rat olfactory bulb. Exp Brain Res. 1983; 50:329-40. [PubMed: 6641865]

56. Lois C, Alvarez-Buylla A. Long-distance neuronal migration in the adult mammalian brain. Science. 1994; 264:1145-48. [PubMed: 8178174]

57. Lledo PM, Saghatelyan A. Integrating new neurons into the adult olfactory bulb: joining the network, life-death decisions, and the effects of sensory experience. Trends Neurosci. 2005; 28:248-54. [PubMed: 15866199] 
58. Luskin MB. Restricted proliferation and migration of postnatally generated neurons derived from the forebrain subventricular zone. Neuron. 1993; 11:173-89. [PubMed: 8338665]

59. Alvarez-Buylla A, Garcia-Verdugo JM. Neurogenesis in adult subventricular zone. J Neurosci. 2002; 22:629-34. [PubMed: 11826091]

60. Bailey MS, Puche AC, Shipley MT. Development of the olfactory bulb: evidence for glia-neuron interactions in glomerular formation. J Comp Neurol. 1999; 415:423-48. [PubMed: 10570454]

61. Hinds JW. Autoradiographic study of histogenesis in the mouse olfactory bulb. I. Time of origin of neurons and neuroglia. J Comp Neurol. 1968; 134:287-304. [PubMed: 5721256]

62. Rogelius N, Ericson C, Lundberg C. In vivo labeling of neuroblasts in the subventricular zone of rats. J Neurosci Meth. 2005; 142:285-93.

63. Alonso M, Viollet C, Gabellec MM, Meas-Yedid V, Olivo-Marin JC, Lledo PM. Olfactory discrimination learning increases the survival of adult-born neurons in the olfactory bulb. $\mathrm{J}$ Neurosci. 2006; 26:10508-13. [PubMed: 17035535]

64. Gheusi G, Cremer H, McLean H, Chazal G, Jean-Didier V, Lledo PM. Importance of newly generated neurons in the adult olfactory bulb for odor discrimination. PNAS. 2000; 97:1823-28. [PubMed: 10677540]

65. Lagier S, Panzanelli P, Russo RE, Nissant A, Bathellier B, Pognetto MS, Fritschy JM, Lledo PM. GABAergic inhibition at dendrodendritic synapses tunes oscillations in the olfactory bulb. PNAS. 2007; 104:7259-64. [PubMed: 17428916]

66. Nusser Z, Kay LM, Laurent G, Homanics GE, Mody I. Disruption of GABAA receptors on GABAergic interneurons leads to increased oscillatory power in the olfactory bulb network. J Neurophysiol. 2001; 86:2823-33. [PubMed: 11731539]

67. Rochefort C, Gheusi G, Vincent JD, Lledo PM. Enriched odor exposure increases the number of newborn neurons in the adult olfactory bulb and improves odor memory. J Neurosci. 2002; 22:2679-89. [PubMed: 11923433]

68. So K, Moriya T, Nishitani S, Takahashi H, Shinohara K. The olfactory conditioning in the early postnatal period stimulated neural stem/progenitor cells in the subventricular zone and increased neurogenesis in the olfactory bulb of rats. Neuroscience. 2008; 151:120-8. [PubMed: 18093744]

69. Diaz J, Samson HH. Impaired brain growth in neonatal rats exposed to ethanol. Science. 1980; 208:751-3. [PubMed: 7189297]

70. Han JY, Joo Y, Kim YS, Lee YK, Kim HJ, Cho GJ, Choi WS, Kang SS. Ethanol induces cell death by activating caspase-3 in the rat cerebral cortex. Mol Cells. 2005; 20:189-95. [PubMed: 16267392]

71. Tsuji R, Fattori V, Abe S, Costa LG, Kobayashi K. Effects of postnatal ethanol exposure at different developmental phases on neurotrophic factors and phosphorylated proteins on signal transductions in rat brain. Neurotoxicol Teratol. 2008; 30:228-33. [PubMed: 18358698]

72. Kumada T, Lakshmana MK, Komuro H. Reversal of neuronal migration in a mouse model of fetal alcohol syndrome by controlling second-messenger signaling. J Neurosci. 2006; 26:742-56. [PubMed: 16421294]

73. Jiang Y, Kumada T, Bryant Cameron D, Komuro H. Cerebellar granule cell migration and the effects of alcohol. Dev Neurosci. 2008; 30:7-23. [PubMed: 18075250]

74. Kumada T, Jiang Y, Bryant Cameron D, Komuro H. How does alcohol impair neuronal migration? J Neurosci Res. 2007; 85:465-70. [PubMed: 17139684]

75. Altman J. Autoradiographic and histological studies of postnatal neurogenesis. IV. Cell proliferation and migration in the anterior forebrain, with special reference to persisting neurogenesis in the olfactory bulb. J Comp Neurol. 1969; 137:433-58. [PubMed: 5361244]

76. Bonthius DJ, Bonthius NE, Napper RMA, West JR. Early postnatal alcohol exposure acutely and permanently reduces the number of granule cells and mitral cells in the rat olfactory bulb: A stereological study. J Comp Neurol. 1992; 324:557-66. [PubMed: 1430337]

77. Maier SE, Miller JA, Blackwell JM, West JR. Fetal alcohol exposure and temporal vulnerability: Regional differences in cell loss as a function of the timing of binge-like alcohol exposure during brain development. Alcohol Clin Exp Res. 1999; 23:726-34. [PubMed: 10235310]

78. Bond NW. Prenatal alcohol exposure in offspring hyperactivity: The effects of home cage shavings and test chamber temperature. Physiol Psychol. 1985; 13:248-52. 
79. Driscoll CD, Streissguth AP, Riley EP. Prenatal alcohol exposure: comparability of effects in humans and animal models. Neurotoxicol Teratol. 1990; 12:231-7. [PubMed: 2196422]

80. National Institute of Health. National Research Council. Guide for the care and use of laboratory animals. Washington, DC: National Academy Press; 1996. Institute of laboratory animal resources, commission on life sciences.

81. Domínguez HD, Chotro MG, Molina JC. Alcohol in the amniotic fluid prior to cesarean delivery: Effects of subsequent exposure to alcohol odor upon alcohol responsiveness. Behav Neural Biol. 1993; 60:129-38. [PubMed: 8117238]

82. Hunt PS, Kraebel KS, Rabine H, Spear LP, Spear NE. Enhanced ethanol intake in preweanling rats following exposure to ethanol in a nursing context. Dev Psychobiology. 1993; 26:133-53.

83. Molina JC, Serwatka J, Enters K, Spear LP, Spear NE. Acute alcohol intoxication disrupts brightness but not olfactory conditioning in preweanling rats. Behav Neurosci. 1987; 101:846-53. [PubMed: 3426798]

84. Spear NE, Specht SM, Kirstein CL, Kuhn CM. Anterior and posterior, but not cheek, intraoral cannulation procedures elevate serum corticosterone levels in neonatal rat pups. Dev Psychobiology. 1989; 22:401-12.

85. Hoffman H, Molina JC, Kucharski D, Spear NE. Further examination of ontogenetic limitations on conditioned taste aversion. Dev Psychobiology. 1987; 20:455-63.

86. Dominguez HD, Bocco G, Chotro MG, Spear NE, Molina JC. Aversions to alcohol's orosensory cues in infant rats: responsiveness to such stimuli when configured with sucrose or sodium chloride. Alcohol. 1994; 11:225-33. [PubMed: 8060523]

87. Pautassi RM, Godoy JC, Spear NE, Molina JC. Early responsiveness to stimuli paired with different stages within the state of alcohol intoxication. Alcohol Clin Exp Res. 2002; 26:644-54. [PubMed: 12045472]

88. Quertemont E, Grant KA, Correa M, Arizzi MN, Salamone JD, Tambour S, Aragon CMG, McBride WJ, Rodd ZA, Goldstein A, Zaffaroni A, Li TK, Pisano M, Diana M. The role of acetaldehyde in the central effects of ethanol. Alcohol Clin Exp Res. 2005; 29:221-34. [PubMed: 15714045]

89. Zimatkin SM, Liopo AV, Deitrich RA. Distribution and kinetics of ethanol metabolism in rat brain. Alcohol Clin Exp Res. 1998; 22:1623-7. [PubMed: 9835273]

90. West MJ. New stereological methods for counting neurons. Neurobiol Aging. 1993; 44:275-85. [PubMed: 8367009]

91. West MJ, Slomianka L, Gundersen HJ. Unbiased stereological estimation of the total number of neurons in the subdivisions of the rat hippocampus using the optical fractionator. Anat Rec. 1991; 231:482-97. [PubMed: 1793176]

92. West MJ, Østergaard K, Andreassen OA, Finsen B. Estimation of the number of somatostatin neurons in the striatum: an in situ hybridization study using the optical fractionator method. $\mathbf{J}$ Comp Neurol. 1996; 37:11-22. [PubMed: 8797153]

93. Pomeroy S, LaMantia AS, Purves D. Postnatal construction of neural circuitry in the mouse olfactory bulb. J Neurosc. 1990; 70:1952-66.

94. Gundersen HJG. Notes on the estimation of the numerical densityof particles: The edge effect. J Microsc. 1977; 111:219-23.

95. Gundersen HJG. Stereology of arbitrary particles. A review of unbiased number and size estimators and the presentation of new ones, in memory of William R. Thompson. J Microsc. 1986; 143:3-45. [PubMed: 3761363]

96. Gundersen HJG, Bagger P, Bendtsen TF, Evans SM, Korbo L, Marcussen N, Møller A, Nielsen K, Nyengaard JR, Pakkenberg B, Sørensen FB, Vesterby A, West MJ. The new stereological tools: disector, fractionator, nucleator and point sampled intercepts and their use in pathological research and diagnosis. APMIS. 1988; 96:857-81. [PubMed: 3056461]

97. West MJ, Gundersen HJ. Unbiased stereological estimation of the number of neurons in the human hippocampus. J Comp Neurol. 1990; 296:1-22. [PubMed: 2358525]

98. Sterio DC. The unbiased estimation of number and sizes of some arbitrary particles using the disector. J Microsc. 1984; 134:127-36. [PubMed: 6737468] 
99. Gundersen HJG, Jensen EB. The efficiency of systematic sampling in stereology and its prediction. J Microsc. 1987; 147:229-63. [PubMed: 3430576]

100. Pautassi RM, Molina JC, Spear N. Infant rats exhibit aversive learning mediated by ethanol's orosensory effects but are positively reinforced by ethanol's post-ingestive effects. Pharmacol Biochem Behav. 2008; 88:393-402. [PubMed: 17936347]

101. Bannoura MD, Kraebel KS, Spear LP, Spear NE. Effects of preweanling ethanol odor exposure on ethanol preference. Alcohol. 1998; 15:213-17. [PubMed: 9539378]

102. Molina JC, Serwatka J, Spear NE. Changes in alcohol intake resulting from prior experiences with alcohol odor in young rats. Pharmacol Biochem Behav. 1984; 21:387-91. [PubMed: 6093151]

103. Molina JC, Serwatka J, Spear NE. Alcohol drinking patterns of young adult rats as a function of infantile aversive experiences with alcohol odor. Behav Neural Biol. 1986; 46:257-71. [PubMed: 3028363]

104. Myers ML, Miller SS, Molina JC, Spear NE. High affinity for ethanol ingestion during the course of early ontogeny in genetically heterogenous rats. Alcohol Clin Exp Res. 2007; (suppl 2):21A.

105. Chotro MG, Alonso G. Stimulus preexposure reduces generalization of conditioned taste aversions between alcohol and non-alcohol flavors in infant rats. Behav Neurosci. 2003; 117:113-22. [PubMed: 12619914]

106. Molina JC, Ponce LF, Truxell E, Spear NE. Infantile sensitivity to ethanol's motivational effects: ethanol reinforcement during the third postnatal week. Alcohol Clin Exp Res. 2006; 30:1506-19. [PubMed: 16930213]

107. Molina JC, Pautassi RM, Truxell E, Spear N. Differential motivational properties of ethanol during early ontogeny as a function of dose and postadministration time. Alcohol. 2007; 41:4155. [PubMed: 17452298]

108. Baer JS, Sampson PD, Barr HM, Connor PD, Streissguth AP. A 21- year longitudinal analysis of the effects of prenatal alcohol exposure on young adult drinking. Arch Gen Psychiatry. 2003; 60:377-85. [PubMed: 12695315]

109. Schneider ML, Moore CF, Kraemer GW. Moderate alcohol during pregnancy: learning and behavior in adolescent rhesus monkeys. Alcohol Clin Exp Res. 2001; 25:1383-92. [PubMed: 11584160]

110. Thomas JD, Garrison M, O’Neill TM. Perinatal choline supplementation attenuates behavioral alterations associated with neonatal alcohol exposure in rats. Neurotoxicol Teratol. 2004; $26: 35$ 45. [PubMed: 15001212]

111. Domínguez HD, López MF, Chotro MG, Molina JC. Perinatal responsiveness to alcohol's chemosensory cues as a function of prenatal alcohol administration during gestational days 17 20 in the rat. Neurobiol Learn Mem. 1996; 65:103-12. [PubMed: 8833099]

112. Hamrick WD, Wilson DA, Sullivan RM. Neural correlates of memory for odor detection conditioning in adults rats. Neurosci Lett. 1993; 163:36-40. [PubMed: 8295728]

113. Nair HP, Gonzalez-Lima F. Extinction of behavior in infant rats: Development of functional coupling between septal, hippocampal and ventral tegmental regions. J Neurosci. 1999; 19:864655. [PubMed: 10493765]

114. Sullivan RM, Wilson DA. Molecular biology of early olfactory memory. Learn Mem. 2003; 10:1-4. [PubMed: 12551958]

115. Roth, TL.; Wilson, DA.; Sullivan, RM. Neurobehavioral development of infant learning and memory: Implications for infant attachment. In: Slater, PJB.; Rosenblatt, JS.; Snowdon, CT.; Roper, TJ.; Brockman, HJ.; Naguib, M., editors. Advances in the study of behavior. San Diego: Academic Press; 2004. p. 103-33.

116. Sullivan RM, Holman PJ. Transitions in sensitive period attachment learning in infancy: the role of corticosterone. Neurosci Biobehav Rev. 2010; 34:835-44. [PubMed: 19931556]

117. Gianoulakis C. Endogenous opioids and addiction to alcohol and other drugs of abuse. Curr Top Med Chem. 2004; 4:39-50. [PubMed: 14754375]

118. Pautassi RM, Nizhnikov ME, Spear NE. Assessing appetitive, aversive, and negative ethanolmediated reinforcement through an immature rat model. Neurosci Biobehav Rev. 2009; 33:95374. [PubMed: 19428502] 
119. Spear NE, Molina JC. Fetal or infantile exposure to ethanol promotes ethanol ingestion in adolescence and adulthood: A theoretical review. Alcohol Clin Exp Res. 2005; 29:909-29. [PubMed: 15976517]

120. Katz LC, Shatz CJ. Synaptic activity and the construction of cortical circuits. Science. 1996; 274:1133-8. [PubMed: 8895456]

121. Linden R. The survival of developing neurons: a review of afferent control. Neuroscience. 1994; 4:671-82. [PubMed: 8190251]

122. Pueta M, Rovasio RA. Ethanol induced changes upon migrational parameters of in vitro neural progenitors of the olfactory interneurons. Biocell. 2007; (suppl 32):222.

123. Woo CC, Hingco EE, Taylor GE, Leon M. Exposure to a broad range of odorants decreases cell mortality in the olfactory bulb. Neuroreport. 2006; 17:817-21. [PubMed: 16708021]

124. Chotro MG, Arias C. Exposure to low and moderate doses of alcohol on late gestation modifies infantile response to and preference for alcohol in rats. Ann Ist Super Sanita. 2006; 42:22-30. [PubMed: 16801722]

125. Bachmanov AA, Kiefer SW, Molina JC, Tordoff MG, Duffy VB, Bartoshuk LM, Mennella JA. Chemosensory factors influencing alcohol perception, preferences and consumption. Alcohol Clin Exp Res. 2003; 27:220-31. [PubMed: 12605071]

126. Kiefer SW. Alcohol palatability and taste reactivity. Neurosci Biobehav Rev. 1995; 19:133-41. [PubMed: 7770193]

127. Light KE, Belcherb ASM, Pierce DR. Time course and manner of Purkinje neuron death following a single ethanol exposure on postnatal day 4 in the developing rat. Neuroscience. 2002; 114:327-37. [PubMed: 12204202]

128. Olney JW, Wozniak DF, Farber NB, Jevtovi-Todorovi V, Bittigau P, Ikonomidou C. The enigma of fetal alcohol neurotoxicity. Trends Mol Med. 2002; 34:109-19.

129. Youngentob SL, Kent PF, Sheehe PR, Molina JC, Spear NE, Youngentob LM. Experienceinduced fetal plasticity: The effect of gestational ethanol exposure on the behavioral and neurophysiologic olfactory response to ethanol odor in early postnatal and adult rats. Behav Neurosci. 2007; 121:1293-305. [PubMed: 18085882]

130. Youngentob SL, Molina JC, Spear NE, Youngentob LM. The effect of gestational ethanol exposure on voluntary ethanol intake in early postnatal and adult rats. Behav Neurosci. 2007; 121:1306-15. [PubMed: 18085883]

131. Youngentob SL, Glendinning JI. Fetal ethanol exposure increases ethanol intake by making it smell and taste better. PNAS. 2009; 106:5359-54. [PubMed: 19273846]

132. Arias C, Molina JC, Spear NE. Differential role of micro, delta and kappa opioid receptors in ethanol-mediated locomotor activation and ethanol intake in preweanling rats. Physiol Behav. 2010; 99:348-54. [PubMed: 19954749]

133. Tabakoff B, Saba L, Printz M, Flodman P, Hodgkinson C, Goldman D, Koob G, Richardson HN, Kechris K, Bell RL, Hübner N, Heinig M, Pravenec M, Mangion J, Legault L, Dongier M, Conigrave KM, Whitfield JB, Saunders J, Grant B, Hoffman PL. WHO/ISBRA Study on State and Trait Markers of Alcoholism. Genetical genomic determinants of alcohol consumption in rats and humans. BMC Biol. 2009; 27(7):70. [PubMed: 19874574]

134. Walker BM, Koob GF. The gamma-aminobutyric acid-B receptor agonist baclofen attenuates responding for ethanol in ethanol-dependent rats. Alcohol Clin Exp Res. 2007; 31:11-8. [PubMed: 17207096]

135. Jeanblanc J, He DY, McGough NN, Logrip ML, Phamluong K, Janak PH, Ron D. The dopamine D3 receptor is part of a homeostatic pathway regulating ethanol consumption. J Neurosci. 2006; 26:1457-64. [PubMed: 16452669]

136. Lee HY, Naha N, Li SP, Jo MJ, Naseer MI, Park MS, Park TJ, Chung BC, Kim MO. In vivo and in vitro ethanol exposure in prenatal rat brain: $\mathrm{GABA}(\mathrm{B})$ receptor modulation on dopamine $\mathrm{D}(1)$ receptor and protein kinase A. Synapse. 2008; 62:534-43. [PubMed: 18435423]

137. Sari Y, Hammad LA, Saleh MM, Rebec GV, Mechref Y. Alteration of selective neurotransmitters in fetal brains of prenatally alcohol-treated C57BL/6 mice: quantitative analysis using liquid chromatography/tandem mass spectrometry. Int J Dev Neurosci. 2010; 28:263-9. [PubMed: 20123123] 
138. Chen S, Charness ME. Ethanol inhibits neuronal differentiation by disrupting activity-dependent neuroprotective protein signaling. PNAS. 2008; 105:19962-7. [PubMed: 19047645] 


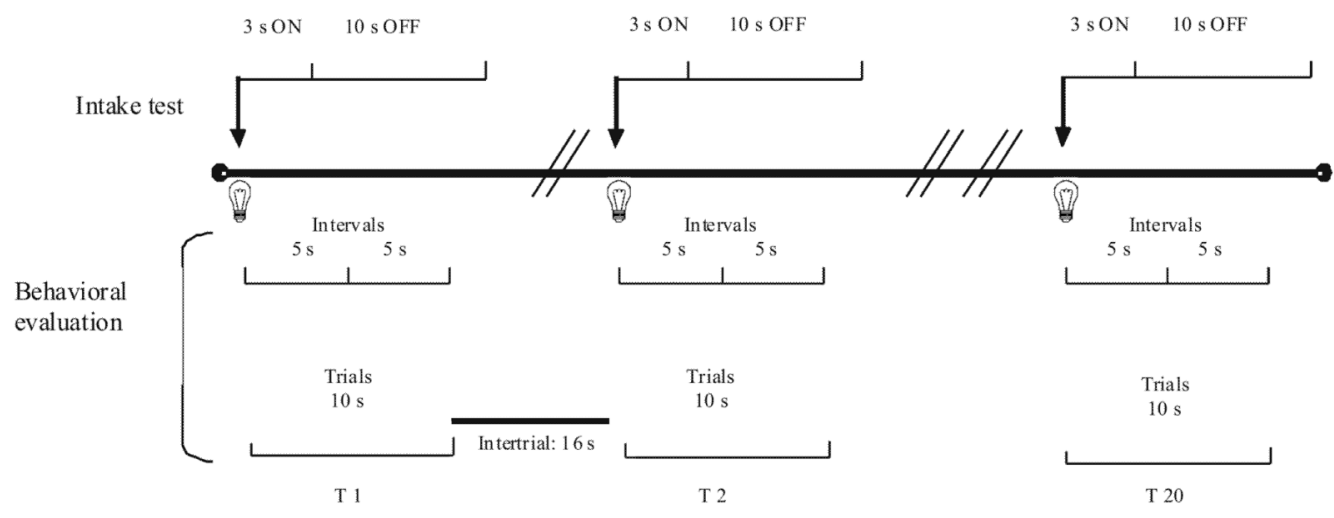

Fig. 1.

Methods for the analysis of behavioral activity during intake test in preweanling rats. Wall climbing and locomotion was registered at 20 trials of $10 \mathrm{~s}$, each; light indicates that the solution was delivered (see text). T: trial. 


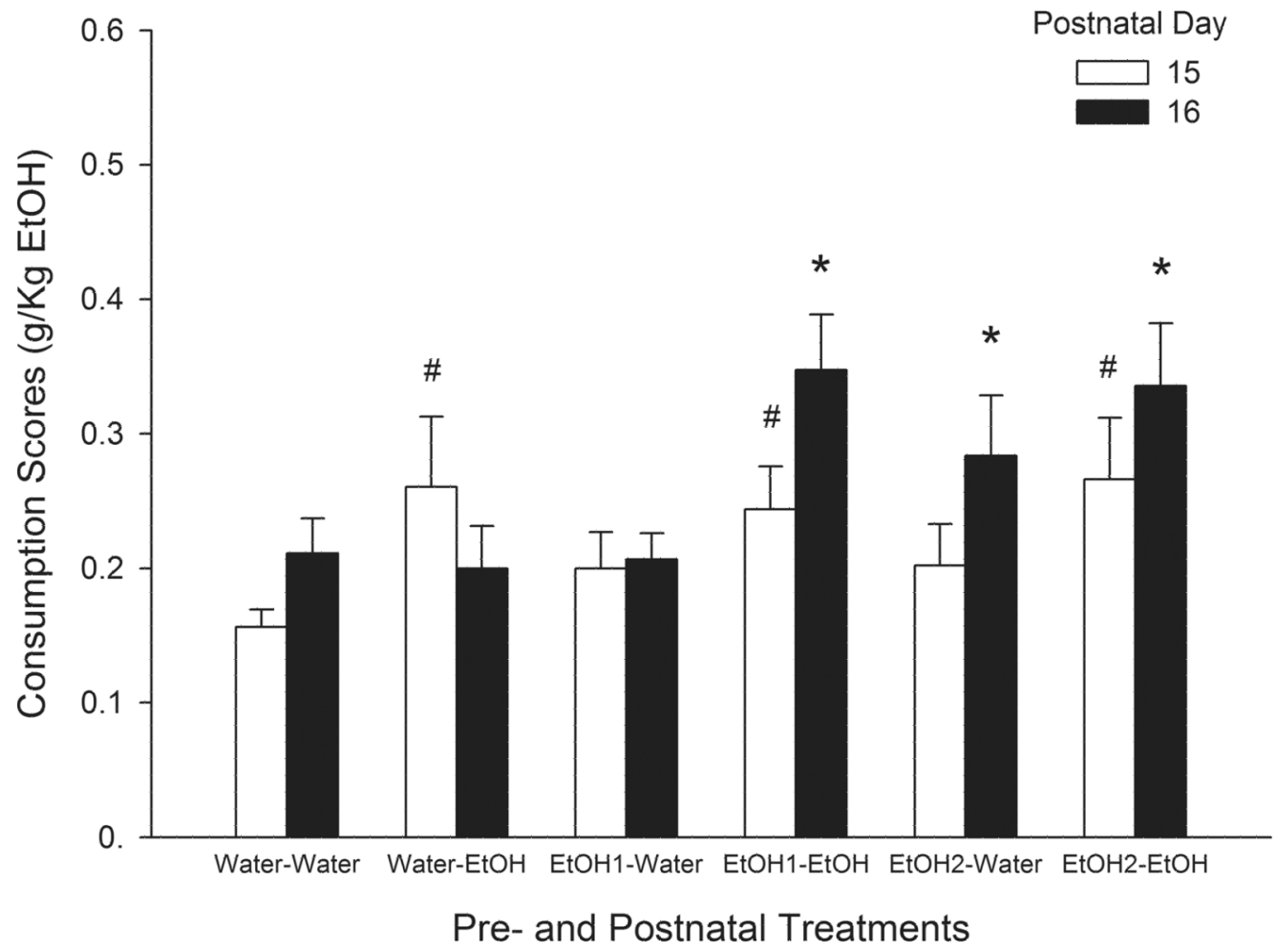

Fig. 2.

Ethanol consumption scores $(\mathrm{g} / \mathrm{kg}$ etoh) of a $5.0 \% \mathrm{v} / \mathrm{v}$ ethanol solution in preweanlings at PDs 15 and 16 as a function of pre- and postnatal treatments. The symbol \# denotes significant differences related to remaining groups at PD 15 . The symbol * denotes significant differences relative to all the remaining groups. Vertical lines illustrate SEM. 


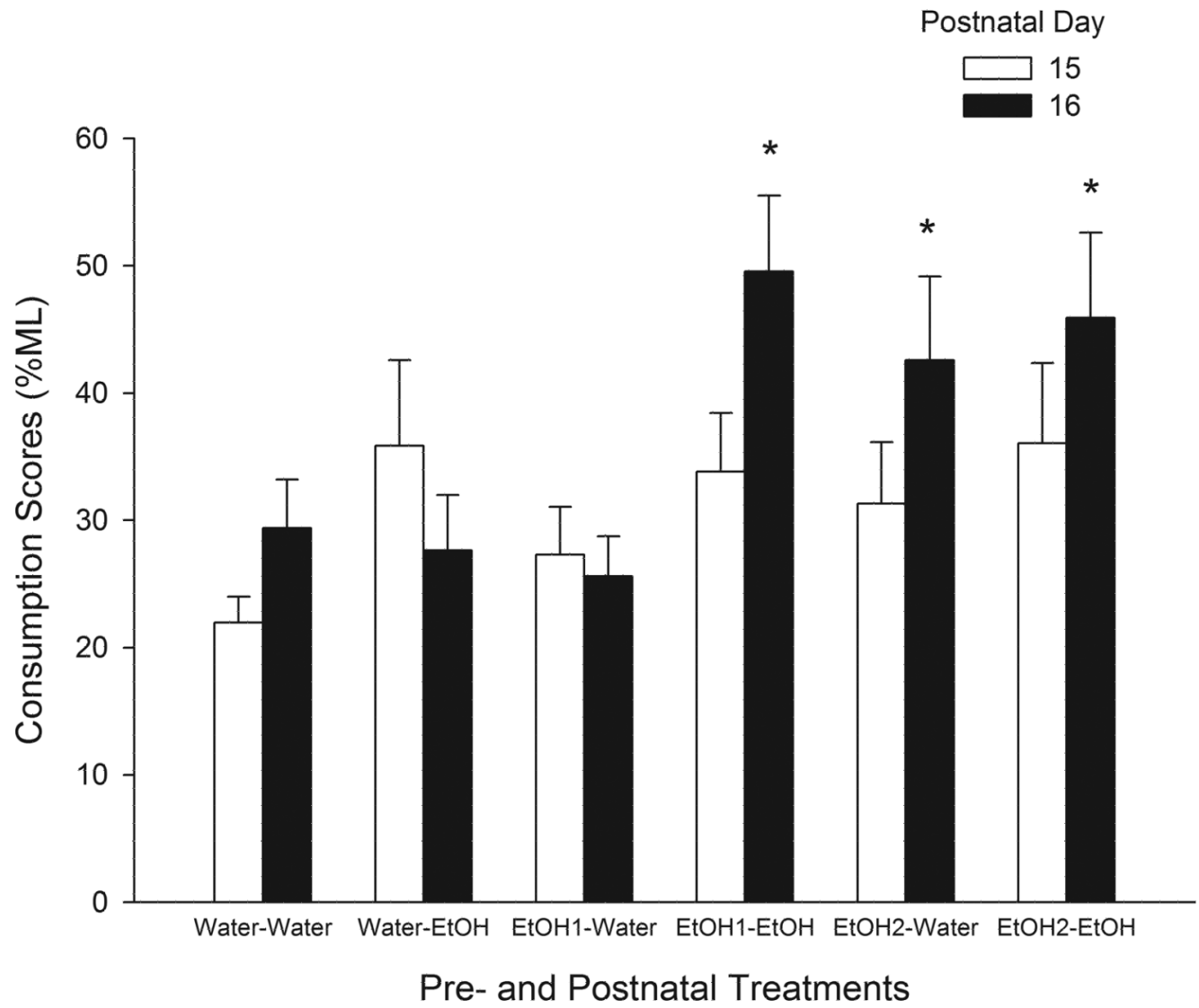

Fig. 3.

Percentage of consumption levels (\% ML) of a $5.0 \% \mathrm{v} / \mathrm{v}$ ethanol solution in preweanlings at PDs 15 and 16 as a function of pre- and postnatal treatments.

The symbol * denotes significant differences relative to all the remaining groups. Vertical lines illustrate SEM. 

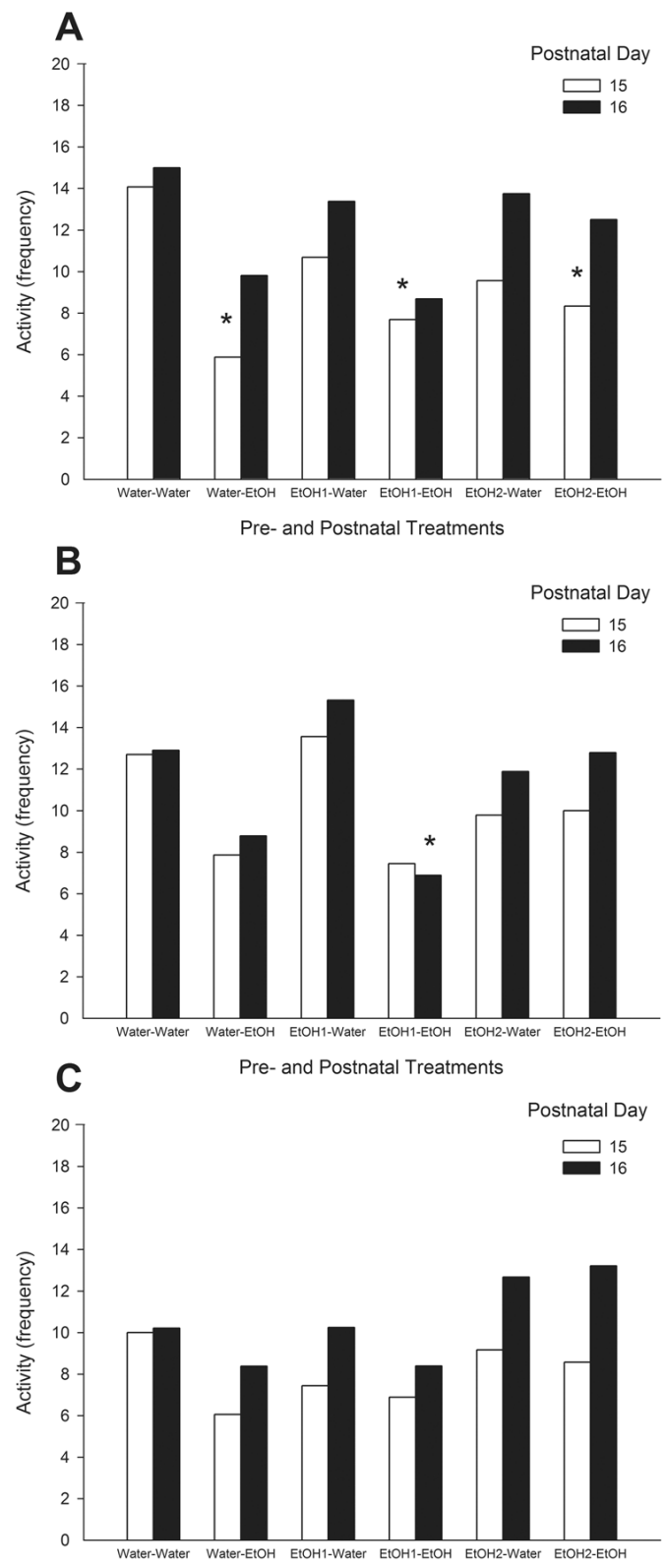

Pre- and Postnatal Treatments

Fig. 4.

Total frequency of motor activity in prewanling rats at PDs 15 and 16 as a function of preand postnatal treatments, when receiving water (A), $5.0 \% \mathrm{v} / \mathrm{v}(\mathrm{B})$ or $10.0 \% \mathrm{v} / \mathrm{v}(\mathrm{C})$ ethanol solutions. The symbol * denotes significant differences relative to control group (waterwater) that receives the same solution at the same day. 


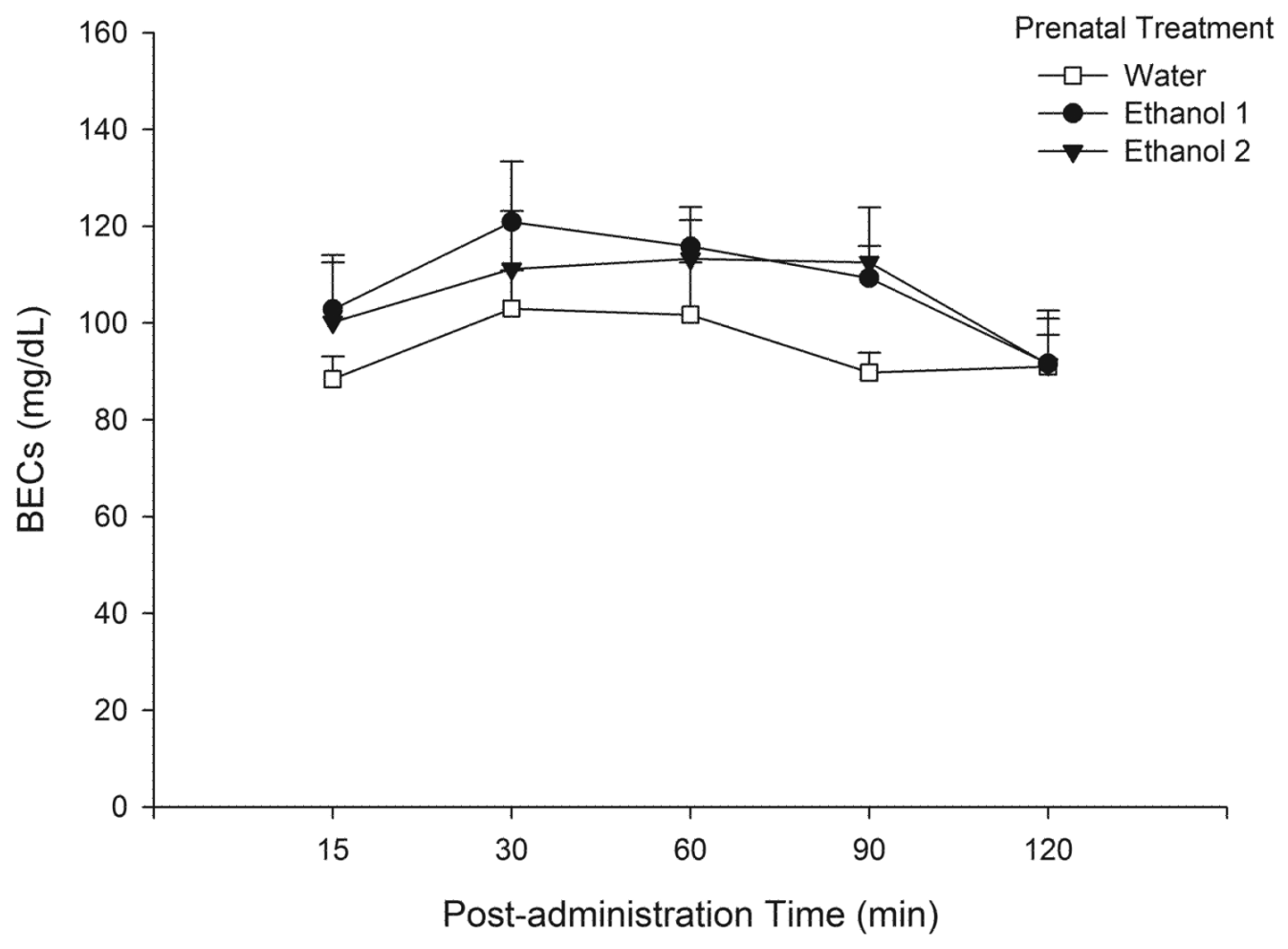

Fig. 5.

Pups blood ethanol concentrations at PD 6 when received an i.g. $1.5 \mathrm{~g} / \mathrm{kg}$ ethanol dose. The data are depicted as a function of prenatal treatment and post-administration time. Vertical lines illustrate SEM. 
A)

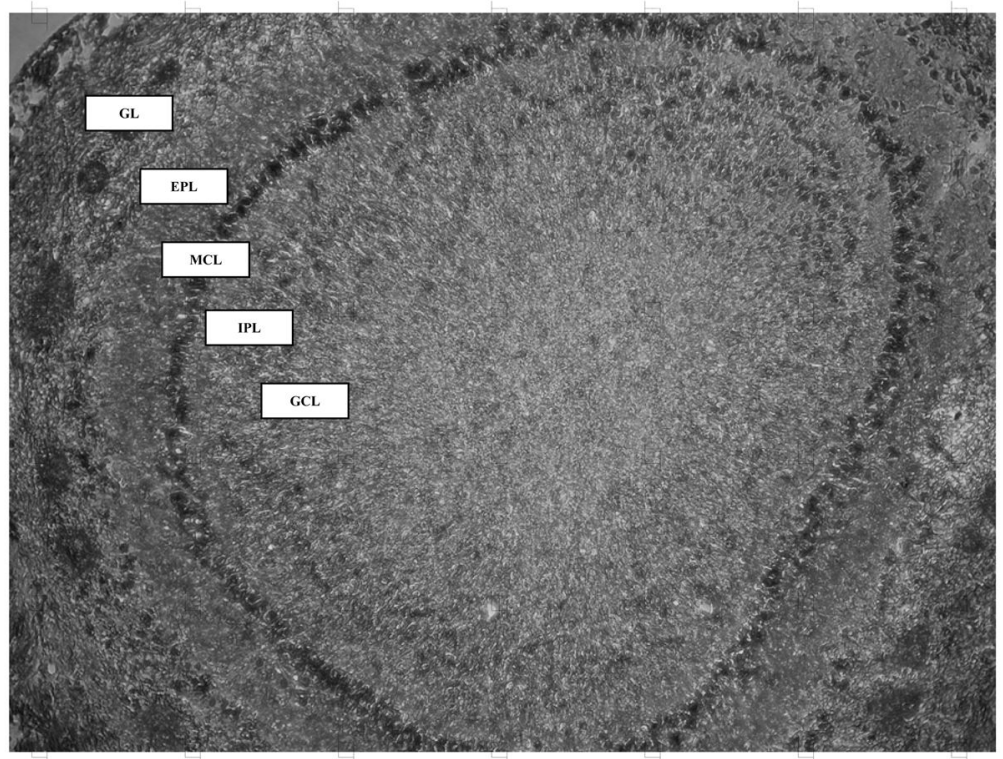

B)

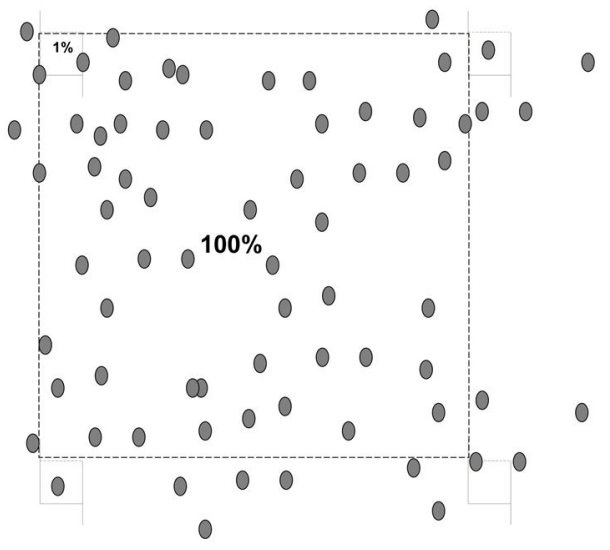

C)

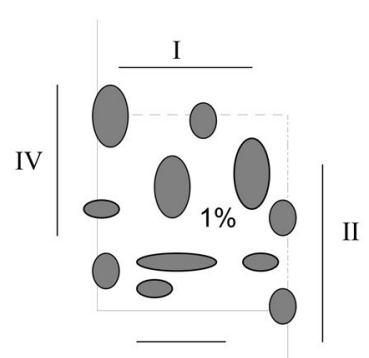

III

Fig. 6.

Diagrammatic summary of the sampling scheme used to estimate total number of GCs in the GCL of the MOB of rats at PD 7 (see text). (A): Low power micrograph of a 16-um-thick cryostat section from olfactory bulb. Superimposed on the section are the grid that illustrates the relative size of the optical dissectors used for counting and the distance between optical dissector samples. GC: glomerular layer; EPL: external plexiform layer; MCL: mitral cell layer; IPL: internal plexiform layer; GCL: granular cell layer. (B): Demarcation of the knowing area $(100 \%)$ to determine the dissector area (1\%). (C): Each dissector has two borders to cells inclusion (I, II) and two of exclusion (III, IV). 


\section{Table 1}

Consumption levels of water (\% ML) in preweanlings during PDs 15 and 16 as a function of pre- and postnatal treatments.

\begin{tabular}{ccc}
\hline Pre- and Postnatal treatments & PD 15 $^{\boldsymbol{a}}$ & PD 16 $^{\boldsymbol{a}}$ \\
\hline Water-Water & $24.28 \pm 2.53$ & $26.62 \pm 3.52$ \\
Water-EtOH & $22.38 \pm 2.85$ & $23.85 \pm 5.45$ \\
EtOH 1-Water & $17.86 \pm 4.03$ & $21.13 \pm 2.85$ \\
EtOH 1-EtOH & $26.13 \pm 7.85$ & $37.28 \pm 9.00$ \\
EtOH 2-Water & $20.98 \pm 1.99$ & $27.51 \pm 4.04$ \\
EtOH 2-EtOH & $30.07 \pm 5.08$ & $32.52 \pm 5.74$ \\
\hline
\end{tabular}

${ }^{a}$ All values represent mean $+/-$ standard error of the mean 
Table 2

Consumption levels of $10.0 \%$ v/v ethanol solution (\% ML) in preweanlings during PDs 15 and 16 as a function of pre- and postnatal treatments.

\begin{tabular}{ccc}
\hline Pre- and Postnatal treatments & PD 15 $^{\boldsymbol{a}}$ & PD 16 $^{\boldsymbol{a}}$ \\
\hline Water-Water & $37.58 \pm 4.59$ & $42.32 \pm 5.52$ \\
Water-EtOH & $46.91 \pm 6.93$ & $43.93 \pm 4.15$ \\
EtOH 1-Water & $48.99 \pm 6.54$ & $46.25 \pm 7.42$ \\
EtOH 1-EtOH & $34.64 \pm 7.02$ & $44.73 \pm 6.52$ \\
EtOH 2-Water & $32.38 \pm 5.74$ & $32.43 \pm 4.93$ \\
EtOH 2-EtOH & $49.73 \pm 5.29$ & $48.59 \pm 6.21$ \\
\hline
\end{tabular}

${ }^{a}$ All values represent mean $+/-$ standard error of the mean 


\section{Table 3}

Cell number in the GCL and total number of sections obtained from OB of neonates (PD 7) as a function of prenatal treatment and postnatal i.g. administration.

\begin{tabular}{ccc}
\hline Pre- and Postnatal treatments & Cells number in GCL $\left(\times \mathbf{1 0}^{\mathbf{6}}\right)^{\boldsymbol{a}}$ & Total sections number $^{\boldsymbol{a}}$ \\
\hline Water-Water & $2.60 \pm 0.12$ & $217.5 \pm 7.50$ \\
Water-EtOH & $2.60 \pm 0.16$ & $220 \pm 8.95$ \\
EtOH 2-Water & $2.86 \pm 0.43$ & $222.5 \pm 7.50$ \\
EtOH 2-EtOH & $2.95 \pm 0.08$ & $242.5 \pm 4.79$ \\
\hline
\end{tabular}

${ }^{a}$ All values represent mean $+/-$ standard error of the mean 